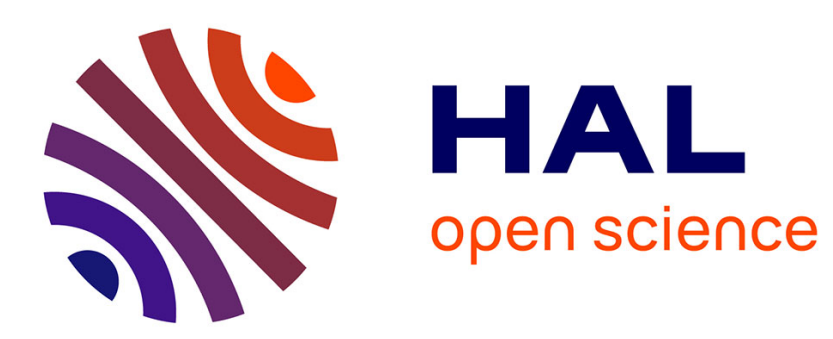

\title{
Effects of organic herbicides on phototrophic microbial communities in freshwater ecosystems
}

\author{
S. Pesce, Agnes Bouchez, B. Montuelle
}

\section{To cite this version:}

S. Pesce, Agnes Bouchez, B. Montuelle. Effects of organic herbicides on phototrophic microbial communities in freshwater ecosystems. Reviews of Environmental Contamination and Toxicology, 2011, 214, p. 87 - p. $124.10 .1007 / 978-1-4614-0668-6 \_5$. hal-00655976

\section{HAL Id: hal-00655976 https://hal.science/hal-00655976}

Submitted on 3 Jan 2012

HAL is a multi-disciplinary open access archive for the deposit and dissemination of scientific research documents, whether they are published or not. The documents may come from teaching and research institutions in France or abroad, or from public or private research centers.
L'archive ouverte pluridisciplinaire HAL, est destinée au dépôt et à la diffusion de documents scientifiques de niveau recherche, publiés ou non, émanant des établissements d'enseignement et de recherche français ou étrangers, des laboratoires publics ou privés. 
D.M. Whitacre (ed)

Reviews of Environmental Contamination and Toxicology 214, 87-124

DOI 10.1007/978-1-4614-0668-6_5, @ S Springer Science+Business Media, LLC 2011

\title{
Effects of Organic Herbicides on Phototrophic Microbial Communities in Freshwater Ecosystems
}

\author{
Stéphane Pesce ${ }^{1}$, Agnès Bouchez ${ }^{2}$, and Bernard Montuelle ${ }^{2}$
}

1. Cemagref, UR MALY, 3 bis quai Chauveau - CP 220, F-69336 Lyon, France e-mail: stephane.pesce@ cemagref.fr

2. INRA, UMR CARRTEL, 75 avenue de Corzent - BP 51174203 Thonon les Bains Cedex, France

\section{Contents}

1 Introduction

2 Experimental Studies

2.1 Effects of Single Herbicides

2.2 Effects of Herbicide Mixtures

3 Field Studies

3.1 Effect of In Situ Exposure on Community Structure and Primary Production

3.2 PICT Approaches

3.3 Recovery Studies

4 Potential Future Areas for Research

4.1 Improving Exposure Assessments

4.2 Improving Assessment of Biological Effects

4.3 Ecosystem Recovery

5 Summary

Acknowledgments

References

Tables

\section{Introduction}

Pollution of aquatic ecosystems by pesticide contamination is a major environmental concern. Numerous authors have addressed the frequent occurrence of chronic or acute herbicide contamination of freshwater ecosystems in both agricultural and urban areas of the world (Devault et al. 2007; Gilliom 2007; Schuler and Rand 2008; Woudneh et al. 2009). The 
physiological characteristics of photosynthetic microorganisms make them attractive as targets for herbicides in aquatic ecosystems. Since these primary producers form the basis of trophic structure in many aquatic environments, herbicides may threaten the entire equilibrium of the ecosystems they contaminate.

The tests that are most widely used to assess the toxicity of herbicides on autotrophic microorganisms (especially microalgae) are monospecific toxicity tests; such tests combine low cost with satisfactory reproducibility and ease of execution (Seguin et al. 2001). The results of single-species toxicity tests with algae have produced large herbicide-dependent sensitivity differences (Table 5.1; DeLorenzo et al. 2001). However, discernment is required when extrapolating results from monospecific assays to ecosystem impairment, and many authors have cited the importance of reinforcing the ecological relevance of toxicological studies to improve ecotoxicological risk assessment (Chapman 2002; Relyea and Hoverman 2006; Filser 2008; Schmitt-Jansen et al. 2008). A first step in such reinforcement is to evaluate toxic effects at the community level by applying community ecology concepts to ecotoxicology testing (Schmitt-Jansen et al. 2008; Clements and Rohr 2009; Geiszinger et al. 2009).

On the basis of the foregoing considerations, the purpose of this paper is as follows:

1. To provide a broad bibliographical review of experimental and in situ studies performed over the last 15 years that address the effects of herbicides, either alone or in pesticide mixtures, on free and attached autotrophic microbial communities

2. To identify potential research areas that can benefit from future research

\section{Experimental Studies}

\subsection{Effects of Single Herbicides}

\subsubsection{Triazines}

\section{- Atrazine}

The effects of atrazine on freshwater phototrophic microorganisms have been widely studied over the past 15 years (Table 5.2; Solomon et al. 1996; DeLorenzo et al. 2001).

\section{- Chronic Effects on Biomass and Primary Production}

Concentrations of chlorophyll a ( $\mathrm{chl}$ a) are generally used to estimate the biomass of photosynthetic microorganisms. Many authors have observed a decrease in phytoplankton chl a (Seguin et al. 2002; Perschbacher et al. 2008) or periphyton chl a (DeLorenzo et al. 1999; Nyström et al. 2000; Seguin et al. 2002; Downing et al. 2004; Rohr and Crumrine 2005; 
Schmitt-Jansen and Altenburger 2005a; Guasch et al. 2007) following atrazine exposure at concentrations ranging from 20 to $1,000 \mathrm{mg} / \mathrm{L}$. At lower concentrations, the effects of atrazine on algal biomass are more variable (Table 5.2). For example, chl a concentrations in phytoplankton (van den Brink et al. 1995; Leboulanger et al. 2001; Relyea 2009) and periphyton (Gruessner and Watzin 1996; Muñoz et al. 2001) were not affected by atrazine concentrations ranging from 5 to $14 \mathrm{mg} / \mathrm{L}$, while Gustavson and Wängberg (1995) observed that $1-20 \mathrm{mg} / \mathrm{L}$ atrazine increased phytoplankton biomass in lake enclosures after 2 weeks of exposure. Similarly, Seguin et al. (2001) showed that phytoplankton chl a concentrations were sometimes higher or lower in outdoor microcosms that were contaminated by $10 \mathrm{mg} / \mathrm{L}$ of atrazine. Atrazine effects on primary production also varied considerably across studies (Table 5.2), and sometimes varied by season (Bérard and Benninghoff 2001) or were affected by trophic interactions (e.g., presence of grazers; Muñoz et al. 2001). These results agreed with those of Detenbeck et al. (1996), who showed in wetland mesocosms that atrazine effects on periphyton differed from a priori predictions that were based on laboratory bioassay data. The reason given was that abiotic parameters, such as temperature or nutrients, grazing intensity and biotic relationship between organisms, had influenced outcomes.

\section{- Chronic Effects on Community Composition}

A series of experimental studies were conducted with atrazine on natural communities from Lake Geneva. Results of these studies revealed that atrazine $(10 \mathrm{mg} / \mathrm{L})$ consistently acted to restructure the autotrophic community, by modifying species composition (Bérard et al.1999a, b; Bérard and Benninghoff 2001; Leboulanger et al. 2001; Seguin et al. 2001). Chlorophytes (especially Chlorella vulgaris) were usually more sensitive, and diatoms and cryptophytes were more tolerant to atrazine, whereas some species, such as the cyanobacterium Oscillatoria limnetica, exhibited a variable response to atrazine that depended on seasons and species interactions (Bérard et al. 1999a, b).

The high sensitivity that chlorophytes had to atrazine was also observed to occur in phytoplankton (Pannard et al. 2009) and periphyton (Downing et al. 2004) assemblages. By contrast, diatoms were often described as being the most tolerant taxa to atrazine effects (Jüttner et al. 1995; DeLorenzo et al. 1999; Downing et al. 2004; Schmitt-Jansen and Altenburger 2005a). However, atrazine effects on community composition were not always detectable in either phytoplankton (van den Brink et al. 1995; Pinckney et al. 2002) or periphyton (Carder and Hoagland 1998). Moreover, in the absence of grazing pressure by snails, Muñoz et al. (2001) found no difference in taxonomic composition between unexposed periphyton, or those exposed to $14 \mathrm{mg} / \mathrm{L}$ atrazine for 18 days. However, they did note that 
atrazine toxicity increased with grazing, and the main effects detected were on algal community structure. The authors divided algal taxa into four classes, based on physiognomy, and concluded that the interaction of atrazine and grazing caused a significant decrease in prostrate growth and filamentous forms that were the most sensitive to atrazine.

\section{- Pollution-Induced Community Tolerance (PICT) Assessment}

Atrazine-induced tolerance in phytoplankton communities occurs, but the results have been variable among experiments. Bérard and Benninghoff (2001) and Seguin et al. (2002) detected a rapid increase in atrazine tolerance in phytoplankton communities that were exposed to 10 and $30 \mathrm{mg} / \mathrm{L}$ atrazine, respectively. Nyström et al. (2000) also observed atrazine-induced tolerance in periphyton exposed to concentrations that ranged between 12 and $125 \mathrm{mg} / \mathrm{L}$. At higher concentrations, such exposure produced severe community damage characterized by reduced algal species number and abundance. By contrast, Gustavson and Wängberg (1995) reported no tolerance induction in phytoplankton and periphyton communities exposed to $20 \mathrm{mg} / \mathrm{L}$ atrazine for 20 days, and Detenbeck et al. (1996) observed that periphyton developed atrazine resistance only at a level equal to or exceeding $50 \mathrm{mg} / \mathrm{L}$. According to Guasch et al. (2007), phosphate concentration is not a parameter that affects atrazine tolerance induction in phototrophic communities.

Interestingly, Schmitt-Jansen and Altenburger (2005a) observed similar ranges of sensitivity by comparing test results from a PICT approach with atrazine and single-species toxicity data (species sensitivity distribution approach; SSD), despite the fact that both approaches utilized test systems of different complexity. The authors emphasized that their SSD approach was facilitated by the existence of a large and comprehensive atrazine toxicity dataset on various algal species.

\section{- $\underline{\text { Irgarol }}$}

Combining short-term bioassay and nanocosm experiments, Nyström et al. (2002) and Bérard et al. (2003) showed that the triazine herbicide Irgarol 1051 was more toxic to Lake Geneva phytoplankton and periphyton than was atrazine. Effects were observed on phytoplankton photosynthetic activity (short-term effects) and diversity (long-term effects after 5-24 days of exposure) from exposure to this herbicide at a level of less than $1 \mathrm{mg} / \mathrm{L}$. Mohr et al. (2008a) also observed effects on planktonic and periphytic algal communities at exposure concentrations between 0.04 and $5 \mathrm{mg} / \mathrm{L}$.

Nyström et al. (2002) and Bérard et al. (2003) concluded that chlorophytes, especially Chlorella vulgaris, were the most Irgarol-sensitive in natural assemblages. By contrast, 
studying highly contaminated ponds ( 1 and $5 \mathrm{mg} / \mathrm{L}$ ), Mohr et al. (2008a) observed a decrease in diatoms and an increase in chlorophytes and cyanobacteria. Given these differences among studies, the authors went on to suggest that Irgarol does not trigger a group-specific response, but rather induced a species-level response.

Mohr et al. (2008a) also revealed that recovery processes vary greatly among free and fixed communities. Indeed, in the same study, the phytoplankton rapidly recovered from a pronounced breakdown immediately after Irgarol exposure, whereas periphytic communities showed no recovery within 150 days after treatment in ponds contaminated by 1 and $5 \mathrm{mg} / \mathrm{L}$ Irgarol. This suggests that the sorption of Irgarol on periphyton may have prolonged the exposure duration in the tested communities.

\section{- $\underline{\text { Other triazines }}$}

\section{-Short-Term Effects}

Brown and Lean (1995) performed bioassays on mesotrophic lake phytoplankton communities using several triazine herbicides (atrazine, simazine, propazine, and prometryn). Atrazine and propazine exerted the highest toxic effects on phosphate and ammonium uptake rates, respectively, whereas prometryn was the most toxic for photosynthetic activity, which was measured by the $[14 \mathrm{C}]$ bicarbonate assimilation rate. Schmitt-Jansen and Altenburger (2005a) confirmed that prometryn is more toxic to periphytic communities than is atrazine in short-term inhibition tests of photosynthesis.

\section{- Chronic Effects and Recovery Processes}

Fairchild and Sappington (2002) conducted a 6-week study in outdoor mesocosms and observed no statistically significant effect of metribuzin on periphyton biomass at concentrations up to $75 \mathrm{mg} / \mathrm{L}$. Similarly, Brock et al. (2004) showed that metribuzin, at nominal concentrations less than or equal to $56 \mathrm{mg} / \mathrm{L}$, had only mild and transient effects on phytoplankton and periphyton, and recovery occurred within 8 weeks. Long-term effects, lasting longer than 8 weeks, were only found in the $180 \mathrm{mg} / \mathrm{L}$ enclosures. In these two experiments, the absence of effects at lower concentrations may have resulted from the rapid dissipation rate of metribuzin in water (half-life of 5-9 days). Brock et al. (2004) found that another triazine herbicide (metamitron; $14-4,480 \mathrm{mg} / \mathrm{L}$ ) was even less persistent in the water column (half-life of 1-3 days). Enclosure experiments with metamitron revealed treatmentrelated effects for photoautotrophic communities only at the two highest concentrations (i.e., 1,120 and 4,480 $\mathrm{mg} / \mathrm{L}$ ), followed by a fast recovery, thought to derive from the agents short dissipation half-life in water. 
When the long-term effects produced by metribuzin and metamitron were compared to data from standard toxicity tests, in which an assessment factor was applied (first-tier approach; i.e., Lowest Observed Effect Concentrations; LOEC), and an SSD approach was used, Brock et al. (2004) concluded that these two assessment procedures proved highly protective, since they did not account for dissipation rate or recovery processes in complex ecosystems.

Gustavson et al. (2003) also recommended that exposure duration be considered when assessing herbicide effects on periphyton communities. Indeed, these authors observed that the effect concentration of metribuzin decreased by one to two orders of magnitude when exposure time increased from 1 to 2 to $24 \mathrm{~h}$. The effect of exposure duration was even more significant for hexazinone. Hexazinone stimulated photosynthesis at the three lowest test concentrations (i.e., 0.4, 2, and $10 \mathrm{mg} / \mathrm{L}$ ) after a 1-h exposure, whereas the stimulation disappeared after $24 \mathrm{~h}$. Moreover, Gustavson et al. (2003) observed a recovery of photosynthetic activity within stream periphyton communities that were exposed to metribuzin for a period up to $48 \mathrm{~h}$, following exposure for $48 \mathrm{~h}$ in herbicide-free water. Photosynthetic activity recovered even at the highest concentration (i.e., $50 \mathrm{mg} / \mathrm{L}$ ), whereas photosynthesis suffered an $80 \%$ inhibition. Comparable recovery processes that occurred within $24 \mathrm{~h}$ after herbicide addition ended were observed by Schneider et al. (1995) for stream periphytic communities exposed to $145-432 \mathrm{mg} / \mathrm{L}$ hexazinone.

\section{-PICT Assessment}

Measures of photosynthetic activity showed that an induced-tolerance existed in communities chronically exposed to prometryn concentrations of $2.5 \mathrm{mg} / \mathrm{L}$ and higher (Altenburger 2005a). Diatom species, especially Nitszchia sp., clearly became predominant following long-term exposure to higher test concentrations (i.e., 160 and $320 \mathrm{mg} / \mathrm{L}$ ), which suggests their high tolerance to prometryn. Similarly, Chang et al. (2011) and Kasai and Hanazato (1995a, b) reported high tolerance of diatom species to another triazine herbicide, simetryn. Kasai and Hanazato (1995b) isolated algal strains from nontreated and treated microcosms that had been exposed for at least 35-days. The authors investigated genetic changes that occurred following simetryn exposure. The most significant finding concerned the chlorophyta Scenedesmus gutwinskii var. heterospina, which exhibited a tolerance level 26-57 times higher for strains preexposed to simetryn than for controls strains. Interestingly, the authors showed that the isolated strains maintained their tolerance for nearly 2 years in the absence of simetryn, confirming the importance of genetic adaptation in tolerance induction, within exposed photoautotrophic communities. 


\subsubsection{Phenylureas}

\section{- Diuron}

\section{-Short-Term Effects}

Brown and Lean (1995) performed a short-term bioassay to test the toxicity of 16 pesticides (including 14 herbicides) to lake phytoplankton. They demonstrated that diuron was the most toxic substance to photosynthetic activity (see Table 5.3). For example, using the same biological end-point, they found that another phenylurea herbicide, monuron, was about 20fold less toxic than was diuron. Francoeur et al. (2007) observed drastic adverse effects of a $20 \mathrm{mM}$ diuron level (i.e., $4.66 \mathrm{mg} / \mathrm{L}$ ) on periphyton photosynthesis after only $5 \mathrm{~min}$ of exposure.

\section{- Chronic Effects and Recovery Processes}

A negative diuron exposure effect was revealed in several studies on chl a levels and on primary production in both phytoplankton (Perschbacher and Ludwig 2004; Knauert et al. 2008, 2009; Knauer et al. 2010) and periphyton (McClellan et al. 2008; Tlili et al. 2008, 2010; Ricart et al. 2009; López-Doval et al. 2010) communities (Table 5.3). Diuron can impact these parameters at exposure concentrations even lower than $0.1 \mathrm{mg} / \mathrm{L}$, within a few weeks of initial contact (McClellan et al. 2008; Ricart et al. 2009). Nevertheless, Tlili et al. (2010) demonstrated that the effects of diuron $(10 \mathrm{mg} / \mathrm{L}$ for 3 weeks $)$ on photosynthetic activity can be inhibited when water contains high $\mathrm{PO}_{4}{ }^{3-}$ concentrations. It has also been shown that a 21-day exposure to $10 \mathrm{mg} / \mathrm{L}$ of diuron inhibited the development of phototrophic communities, whereas they bloomed in untreated microcosms (Pesce et al. 2006).

Phototrophic community composition can also be affected by chronic diuron exposure (Table 5.3), although results vary greatly among various studies. Perschbacher and Ludwig (2004) showed that phytoplankton community composition was impacted by diuron (at 2 and 20 $\mathrm{mg} / \mathrm{L}$ ): cyanobacteria were severely reduced, while diatom and green algae were stimulated. Conversely, McClellan et al. (2008) and Tlili et al. (2010) observed a decrease in the relative number of diatoms in periphyton communities that were exposed to diuron concentrations between 0.02 and $10 \mathrm{mg} / \mathrm{L}$. Ricart et al. (2009) also observed changes in diatom composition of periphyton that were exposed for 29 days to low concentrations of diuron. Their work showed that the most sensitive end point was diatom biovolumes, which significantly decreased in the presence of diuron within 8 days, even in the treatments receiving the lowest concentration (i.e., $0.07 \mathrm{mg} / \mathrm{L}$ ). This result was in accordance with that of Leboulanger et al. (2011), who reported a decrease in phytoplankton biovolumes following a 5-day exposure to 2.2 and $11 \mathrm{mg} / \mathrm{L}$ diuron. 
Using three successive treatments of $5 \mathrm{mg} / \mathrm{L}$ of diuron, Knauert et al. (2009) observed that the herbicide significantly affected phytoplankton density and diversity, during 5 weeks of constant exposure. The most sensitive species were the cryptophyceae Chroomonas acuta and Cryptomonas erosa et ovata. Diuron exhibited a dissipation half-life of 43 days, allowing the phytoplankton community to recover both abundance and diversity during the 33-173 day posttreatment period.

\section{- Chronic Versus Acute Effects}

Tlili et al. (2008) assessed the response of chronically contaminated biofilms (32 days, 1 $\mathrm{mg} / \mathrm{L}$ diuron) to short pulses of diuron exposure ( $3 \mathrm{~h} ; 7$ and $14 \mathrm{mg} / \mathrm{L}$ ). They detected several effects, including a significant increase in chl a fluorescence in periphyton chronically exposed to $1 \mathrm{mg} / \mathrm{L}$ diuron, increases in biomass and photosynthetic carbon incorporation, and changes in algal community structure (assessed by Polymerase Chain Reaction-Denaturing Gradient Gel Electrophoresis (PCR-DGGE) on 18S rDNA gene fragment and pigment analysis). Diuron pulses (single or double pulses at 7 or $14 \mathrm{mg} / \mathrm{L}$ ) inhibited carbon incorporation in all biofilm communities, especially in the control microcosm. Nevertheless, the different pulses only affected community composition in control biofilms, revealing that the impact on a biofilm of a pulsed acute exposure to diuron depends on whether communities had previously been exposed to this herbicide.

\section{-PICT Assessment}

McClellan et al. (2008) observed an increase in community tolerance for long-term concentrations of $0.08-10 \mathrm{mg} / \mathrm{L}$ diuron, whereas a chronic exposure of $50 \mathrm{mg} / \mathrm{L}$ was intolerable for periphyton, which was severely disturbed. Interestingly, the authors emphasized the fact that the observed threshold concentration of $0.08 \mathrm{mg} / \mathrm{L}$, which caused effects on periphyton biomass and composition, as well as a shift in community tolerance, could not be predicted by extrapolation methods such as SSD or acute-to-chronic effect ratios. An increase in periphtyon tolerance was also recorded by Tlili et al. (2010), following a 3week exposure to $10 \mathrm{mg} / \mathrm{L}$ diuron. Their work revealed that phosphate concentration didn't influence diuron tolerance induction in the exposed communities as Guasch et al. (2007) had shown with atrazine. Nevertheless, Tlili et al. (2008) did not detect PICT in periphyton exposed for 32 days to $1 \mathrm{mg} / \mathrm{L}$ diuron. According to the authors, the lack of PICT processes could be due to the regular supply of nonexposed microorganisms in the contaminated microcosms that was provided by water renewal during the experiment. 


\section{- Isoproturon (IPU)}

-Short-Term Effects

Gustavson et al. (2003) measured periphyton photosynthesis following exposure durations of 1 and $24 \mathrm{~h}$, and found no effect concentration (NEC) values of $1 \mathrm{mg} / \mathrm{L}$ and $0.019 \mathrm{mg} / \mathrm{L} \mathrm{IPU}$, respectively. IPU was more toxic than the three other herbicides they tested (i.e., metribuzin, hexazinone, and pendimethalin).

\section{- Chronic Effects, PICT Assessment and Recovery Processes}

Schmitt-Jansen and Altenburger (2005a, b, 2008) performed a series of investigations using $20 \mathrm{~L}$ glass aquaria to evaluate the effects on periphytic communities of a 14- or 28-day exposure to IPU $(2.4-312 \mathrm{mg} / \mathrm{L})$. Periphyton chl a fluorescence was inhibited at IPU concentrations above $20 \mathrm{mg} / \mathrm{L}$, while algal populations shifted from diatoms to chlorophytes at concentrations in the range $20-312 \mathrm{mg} / \mathrm{L}$. At the highest test concentrations, Navicula halophila was predominant in the diatom community (89\%), but microscopy revealed abnormally shaped cells among these organisms. The replacement of diatom species was associated with an increase in tolerance, as was observed in short-term inhibition tests on photosynthesis (using pulse-amplitude-modulated (PAM) fluorometry or 14C-carbonate incorporation). The authors also addressed their difficulty in comparing their observed effects with SSD predictions, because the database used for IPU toxicity on algae was very poor (Schmitt-Jansen and Altenburger 2005a).

In other studies, it was showed that diatom density and composition in periphyton were impacted by IPU at concentrations ranging from 5 to $30 \mathrm{mg} / \mathrm{L}$; in addition, IPU treatments seemed to favor facultative heterotroph diatoms, which are able to switch trophic mode from autotrophy to heterotrophy (Pérès et al. 1996; Debenest et al. 2009). However, Laviale et al. (2010) observed that light, which can be considered as a direct physical stressor, slightly modulated the acute toxic effects of IPU on the photosynthesis of natural periphytic communities.

Knauert et al. (2009) also reported an impact of IPU on density and diversity of phytoplankton communities that were exposed for 5 weeks to a constant nominal IPU concentration of $14 \mathrm{mg} / \mathrm{L}$. The observed effects followed similar patterns to those of diuron in the same study (see Sect. 2.1.2.1), and were followed by a recovery period as IPU dissipated from the water $(\mathrm{t} 1 / 2=35$ days). In contrast to the results described above, Traunspurger et al. (1996) did not find any effects of IPU on phytoplankton cell abundance or community composition at nominal concentrations up to $90 \mathrm{mg} / \mathrm{L}$, following an 8-week exposure. 
However, it is important to note that real IPU concentrations in the microcosms were not monitored, and microcosms were not replicated during this study.

\section{- $\underline{\text { Linuron }}$}

\section{- Chronic Direct Effects}

The chronic effects of linuron on phytoplankton and periphtyon have been investigated using microcosms at concentrations ranging from $0.5 \mathrm{mg} / \mathrm{L}$ (Van Geest et al. 1999) to $500 \mathrm{mg} / \mathrm{L}$ (Daam et al. 2009a). Except for Van Geest et al. (1999), who found that three repeated linuron treatments $(0.5-50 \mathrm{mg} / \mathrm{L}$ at 4-week intervals) caused only negligible changes in algal communities; all studies produced direct and indirect effects on phytoplankton and periphyton (Van den Brink et al. 1997; Slijkerman et al. 2005; Daam et al. 2007, 2009a). In tropical freshwater microcosms, linuron (15-500 mg/L) inhibited photosynthesis and affected both phytoplankton and periphytic communities (Daam et al. 2009a). The most sensitive species were chlorophytes belonging to the genera Scenedesmus, Coelastrum, and Pediastrum (phytoplankton) and the cyanobacterium Chamaesiphon sp. (periphyton). However, given the development of tolerant taxa (mainly belonging to diatom and cryptophyte classes) and functional redundancy, the authors emphasized that chl a concentration was not a sensitive indicator of linuron exposure, especially for the effects on phytoplankton. Daam et al. (2009b) compared the effects of linuron, in a microcosm study carried out in Thailand, with the effects reported in temperate model ecosystem studies. The authors concluded that the sensitivity of primary producers to the effects of linuron was similar among different climatic regions. Such similarity supports the use of toxicity data in tropical regions that were generated in temperate ones.

\section{- Chronic Indirect Effects}

Van den Brink et al. (1997), using macrophyte dominated microcosms, demonstrated that linuron can also indirectly stimulate more tolerant phytoplankton species such as Chlamydomonas sp. Linuron exposure decreased macrophyte biomass, thereby increasing nitrate levels, which, in turn, produced an increase in total phytoplankton chl a levels. Such ecological cascading effects were confirmed by Slijkerman et al. (2005) and Daam and Van den Brink (2007), who showed that linuron-induced primary inhibition of the photosynthetic efficiency of primary producers (including macrophytes) resulted in a significant release of nutrients in the water, which consequently stimulated less-sensitive or fast-adapting phytoplankton species. Van den Brink et al. (1997) and Slijkerman et al. (2005) recorded an increase in flagellates subjected to a linuron treatment regime, whereas Daam and Van den 
Brink (2007) identified the algal genera Ephitema, Navicula, and Closterium as being favored by changes resulting from linuron exposure.

\subsubsection{Chloroacetamides}

\section{- Alachlor and Metolachlor}

The effects of alachlor on periphytic (Spawn et al. 1997) and epipelic (Carder and Hoagland 1998) algal communities have been investigated in stream microcosms. Carder and Hoagland (1998) recorded a decrease in algal biovolumes after a 4-week exposure to $90 \mathrm{mg} / \mathrm{L}$ of alachlor, but no effects were detected at $5 \mathrm{mg} / \mathrm{L}$. The relative abundance of the diatoms Navicula sp. and Gyrosigma exinium significantly decreased following alachlor exposure, but effects persisted only for G. exinium at the highest concentration. Similarly, Spawn et al. (1997) did not observe any significant alachlor effect within 3 weeks of exposure at $1 \mathrm{mg} / \mathrm{L}$, although algal biomass and cell densities were inhibited at all other concentrations (i.e., 10, 30,100 , and $1,000 \mathrm{mg} / \mathrm{L}$ ). There was a shift in the dominant algae at concentrations of 30 $\mathrm{mg} / \mathrm{L}$ and higher. The centric diatom Melosira varians was the most affected by alachlor, but other centric diatoms were not affected, demonstrating that similar taxa may exhibit different responses to this herbicide. By contrast, Debenest et al. (2009) showed that $30 \mathrm{mg} / \mathrm{L}$ of the chloroacetamide herbicide s-metolachlor had no effect on the abundance of M. varians, following a 3-day exposure. However, other diatom species such as Eolimna minima and Navicula reichardtiana proved sensitive to this herbicide, and a significant decrease in chl c concentrations and live-cell density was recorded in periphtyon exposed for 3 days to levels of 5 and $30 \mathrm{mg} / \mathrm{L}$. Using complex outdoor microcosms, Relyea (2009) observed no significant effect of metolachlor $(7.4 \mathrm{mg} / \mathrm{L})$ on phytoplankton chl a or periphyton biomass within 16 or 35 days of exposure.

\section{- Other Chloroacetamides}

Mohr et al. (2008b) studied the effects of metazachlor on plankton communities in pond and stream mesocosms over a monitoring period of 140 days. Metazachlor strongly affected both pond and stream communities at concentrations higher than $5 \mathrm{mg} / \mathrm{L}$ (i.e., $20-500 \mathrm{mg} / \mathrm{L}$ ). Direct negative effects were most prominent for chlorophytes, whereas diatoms and cryptophytes seemed insensitive. Moreover, the herbicide remained highly persistent in the mesocosms $\left(\mathrm{t}_{1 / 2}=27-48\right.$ days $)$, and chlorophytes did not recover in the more strongly contaminated stream mesocosms, suggesting potential long-lasting effects of metazachlor on phytoplankton in exposed aquatic ecosystems. This contrasted with the results of Noack et al. 
(2003), who found only slight effects of metazachlor on phytoplankton densities at very high concentrations $(10,000 \mathrm{mg} / \mathrm{L})$, followed by a recovery after 30-35 days. However, these authors advised that their conclusions be accepted with caution, because lack of replicated mesocosms prevented statistical evaluation of results. In model streams, the only effects recorded by Takahashi et al. (2007) on periphyton exposed to pretilachlor (26-382 $\mathrm{mg} / \mathrm{L}$ ) for 7-28 days were a slight increase of Navicula pupula and a slight decrease of Anabaena sp. Using complex outdoor microcosms, Relyea (2009) observed a decrease in phytoplankton chl a after a 16-day exposure to $10 \mathrm{mg} / \mathrm{L}$ acetochlor, whereas periphyton biomass remained unaffected throughout the entire duration of the study (35 days).

\subsubsection{Sulfonylureas}

Using four levels of the sulfonylurea herbicide metsulfuron-methyl $(0,1,5$, and $20 \mathrm{mg} / \mathrm{L})$ in freshwater enclosures, Wendt-Rasch et al. (2003) showed an increase in the biomass of periphytic algae growing on the leaves of the macrophyte Myriophyllum spicatum, after a 2week exposure. They attributed this increase to a possible nutrient leakage from the macrophyte leaves following herbicide exposure. Changes were also detected on the species composition of periphytic algal communities in enclosures exposed to $20 \mathrm{mg} / \mathrm{L}$, while metsulfuron-methyl did not alter phytoplankton community biomass or composition. This suggests that the toxicity of sulfonylurea herbicides on phytoplankton is limited, as asserted by Seguin et al. (2001) and Leboulanger et al. (2001), who showed that nicosulfuron was far less toxic to phytoplankton than was atrazine. Nevertheless, they emphasized that nicosulfuron $(10 \mathrm{mg} / \mathrm{L})$ can affect phytoplankton species composition by inhibiting more diatoms than chlorophytes. Abdel-Hamid et al. (1996) also observed community composition effects on lake phytoplankton from exposure $(1,10$, and $100 \mathrm{mg} / \mathrm{L})$ to another sulfonylurea herbicide, chlorosulfuron.

\subsubsection{Glyphosate}

\section{- Effects of High Glyphosate Concentrations}

Vera et al. (2010) showed that a high concentration of the commercial formulation of Roundup ${ }^{\circledR}(8 \mathrm{mg} / \mathrm{L}$ of the active molecule glyphosate) produced a clear delay in periphytic colonization and reduced periphytic dry weight, as well as chl a, in comparison with control mesocosms. This occurred despite a significant increase in total phosphorus concentrations in the treated mesocosms. Pérez et al. (2007) also observed a significant phosphorus release in mesocosms after the addition of Roundup ${ }^{\circledR}(6$ and $12 \mathrm{mg} / \mathrm{L}$ of the active ingredient 
glyphosate), which was associated with structural changes in the planktonic and periphytic microbial assemblages, within a few days. In treated mesocosms, total phytoplankton abundance decreased, whereas primary production and picocyanobacteria abundance increased. Similar patterns have been observed in periphyton, which showed increasing abundance of cyanobacteria following glyphosate exposure (Vera et al. 2010). Schaffer and Sebetich (2004) also found that Rodeo ${ }^{\circledR}$ treatments $(0.125$ and $12.5 \mathrm{mg} / \mathrm{L}$ of the active ingredient glyphosate) led to significant stimulation of primary productivity of a lake phytoplankton community during a 7-h incubation period. They hypothesized that this effect could have resulted from the use of the nitrogen and phosphorus released through the glyphosate degradation process. Similarly, Relyea (2005) observed an increase in periphytic algal biomass after a 2-week Roundup ${ }^{\circledR}$ exposure (3.8 mg glyphosate/L), which, he suggested, could result from a decrease in grazing pressure caused by Roundup® effects on herbivorous organisms.

\section{- Chronic Effects of Environmentally Relevant Glyphosate Concentrations}

Using a more environmentally relevant glyphosate concentration (i.e., $6.9 \mathrm{mg} / \mathrm{L}$ ), Relyea (2009) showed that Roundup ${ }^{\circledR}$ caused insignificant effects on an aquatic food web comprising periphyton, phytoplankton, and other higher trophic level organisms. This was consistent with results from Pesce et al. (2009), who demonstrated that any effects of glyphosate (10 mg/L; 14 days) on riverine algal communities was limited to ones of community composition (assessed by microscopic identification and PCR-DGGE on 18S rDNA gene fragment). Moreover, effects were only perceptible on communities sampled during the summer, whereas spring communities remained insensitive, revealing that response of natural algae to herbicide exposure can be seasonally dependent. Glyphosate-induced effects (at 1, 10, and $100 \mathrm{mg} / \mathrm{L}$ ) on phytoplankton diversity were also reported by AbdelHamid et al. (1996) in a 13-day outdoor enclosure experiment.

\subsubsection{2,4-Dichlorophenoxyacetic Acid (2,4-D)}

Using bioassays on mesotrophic lake phytoplankton communities exposed to different herbicides, Brown and Lean (1995) showed that 2,4-D exhibited the least toxic effect on photosynthetic activity and phosphate and ammonium uptake rates. This herbicide had EC50 values $(3 \mathrm{~h})$ higher than $33 \mathrm{mg} / \mathrm{L}$ for these three biological end points. Using an 8 -day microcosm study, Kobraei and White (1996) observed a stimulation of primary production in phytoplankton communities exposed to $2 \mathrm{mg} / \mathrm{L}$ of 2,4-D. No stimulation was detected at 10 $\mathrm{mg} / \mathrm{L}$, yet higher concentrations negatively affected phytoplankton. Gross primary production, 
community respiration, chl a concentrations, algal density and biovolumes significantly decreased in the 100 and $1,000 \mathrm{mg} / \mathrm{L}$ microcosms. They found heterotrophic algal taxa to be the least affected by 2,4-D at highest concentrations. Using lower concentrations in large outdoor mesocosms, Relyea $(2005,2009)$ showed that levels of neither $16 \mathrm{mg} / \mathrm{L}$ nor 120 $\mathrm{mg} / \mathrm{L}$ of 2,4-D produced significant direct or indirect effects on periphyton and phytoplankton biomass.

\subsubsection{Other Herbicides}

\section{- Chronic Effects on Biomass and Primary Production}

Testing the effects of ten herbicides commonly applied in rice cultivation (clomazone, thiobencarb, pendimethalin, propanil, quinclorac, halosulfuron, bensulfuronmethyl, triclopyr, 2,4-d-amine, and molinate) in aquaculture ponds at rates equivalent to direct application, Perschbacher et al. (2002) found that, with the exception of propanil, none of the herbicides had any measurable effect on phytoplankton primary production or chl a levels, within 9 exposure days. Propanil stimulated chl a (Perschbacher et al. 1997, 2002). A 3-day microcosm study by Waiser and Robarts (1997) showed that the carbamate herbicide triallate exhibited limited effects on lake phytoplankton biomass, since substantial declines in chl a concentrations only occurred at a triallate concentration of $1 \mathrm{mg} / \mathrm{L}$ (but not 10 and $100 \mathrm{mg} / \mathrm{L}$ ).

\section{- Chronic Effects on Community Composition}

Caquet et al. (2005) investigated the effects of the herbicide fomesafen (40 mg/L), alone and in combination with an adjuvant (Agral 90, $90 \mathrm{mg} / \mathrm{L}$ ), on plankton communities in outdoor mesocosms over a 9-month period. They found that Agral 90 did not influence the effect of fomesafen on phytoplankton. Fomesafen inhibited Chlorophyceae but produced abundance and biovolume increases of Cyanobacteria, Cryptophycea, Dinophycea, and Bacillariophycea, thus enhancing taxonomic phytoplankton diversity. Phytoplankton community composition was also affected by the herbicide methabenzthiazuron, during a 5-month microcosm study (Wellmann et al. 1998). Population dynamics were dependent on herbicide concentrations as well as light intensity, temperature, and nutrient concentrations. Primary production was temporarily inhibited at metabenzthiazuron concentrations ranging from 89 to $3,371 \mathrm{mg} / \mathrm{L}$, while lower concentrations (10, 21 and $43 \mathrm{mg} / \mathrm{L}$ ) induced no or only transient weak responses in the phytoplankton. The most sensitive algae belonged to Chlorophyceae, whereas Cryptophycea exhibited strong recovery at the higher concentrations during the study period. In field-paddy mesocosms, Sánchez et al. (2006) observed no significant effect of the rice herbicide profoxydim (at rates from 45 to $377 \mathrm{~g} / \mathrm{ha}$ ) on phytoplankton density and 
composition, within 9 exposure days. Using in situ enclosures, Faber et al. (1998) tested the effect of the herbicides glufosinate- ammonium and bialaphos on phytoplankton communities in a eutrophic lake. At the highest treatment levels $(10 \mathrm{mg} / \mathrm{L})$, both herbicides caused a significant decrease in small phytoplankton cell species $(1-3 \mathrm{~mm})$. The effects were transient, and recovery was observed earlier for bialaphos (14 days post application) than for glufosinate-ammonium (49 day). Larger phytoplankton was generally not adversely impacted by these herbicides.

\subsection{Effects of Herbicide Mixtures}

\subsubsection{Mixtures of Similarly Acting Herbicides}

The effects of mixtures of PS-II inhibitors have been investigated on freshwater microbial communities in several studies; the tested mixtures were of various triazine (Pollehne et al. 1999) and/or phenylurea herbicides (Knauert et al. 2008, 2009; Knauer et al. 2010, Pesce et al. 2010b). Using a 10-day mesocosm approach, Pollehne et al. (1999) found no herbicidespecific effects on estuarine phytoplankton communities exposed to the combined triazines simazine and atrazine, at concentrations of $0.04-6 \mathrm{mg} / \mathrm{L}$ each. Knauert et al. $(2008,2009)$ performed a 5-week outdoor mesocosm study to evaluate the effects of a mixture of equitoxic concentrations of atrazine, isoproturon and diuron on phytoplankton photosynthesis and community succession. The herbicide mixture adversely affected photosynthetic activity and significantly influenced community structure in terms of abundance, diversity, and species composition. The results demonstrated that the combined effects of the three PS-II inhibitors herbicides could be predicted, based on the concept of concentration addition (Faust et al. 1994). This outcome was in line with previous findings from phytoplankton bioassays, in which the combined effects of similarly acting herbicides were assessed (e.g., Faust et al. 2001; Junghans et al. 2003; Chèvre et al. 2006). Similarly, Pesce et al. (2010b), using a PICT approach and photosynthesis bioassays, demonstrated that mixtures of diuron and its metabolite N-(3,4- dichlorophenyl)-N-methylurea (DCPMU) produced additive effects on natural phototrophic biofilm photosynthesis.

Knauer et al. (2010) showed that long-term exposure to PS-II inhibitor mixtures can also induce cotolerance within phytoplankton communities. However, they also demonstrated that even if cotolerance is expected for compounds having similar biochemical modes of action, this cotolerance may vary among molecules (in their study, atrazine, isoproturon, and diuron). 


\subsubsection{Mixtures of Dissimilarly Acting Herbicides}

Carder and Hoagland (1998) and Hartgers et al. (1998) assessed the effects of mixtures of PSII inhibitors (triazine and/or phenylurea) and the chloroacetanilides, which are known to affect fatty acid metabolism (Couderchet et al. 1998). The effects of a combination of atrazine (12 and $150 \mathrm{mg} / \mathrm{L}$ ) and alachlor (5 and $90 \mathrm{mg} / \mathrm{L}$ ) on benthic algal communities in artificial streams appeared to be additive rather than synergistic and led to a significant decrease in cell biovolumes throughout the 4-week experiment (Carder and Hoagland 1998). Hartgers et al. (1998) assessed the response of phytoplankton communities to a mixture of atrazine, diuron, and metolachlor in 28-day freshwater microcosms $(600 \mathrm{~L})$; concentrations were $0.01-1.0$-fold the EC50 (72 h) values. These EC50 values were obtained in standard algal tests using Selenastrum capricornutum and were performed to comply with OECD guidelines. Direct effects were detected at 0.3-fold the EC50 treatment level and higher. Effects included a drop in photosynthetic efficiency and a decrease in the abundance of several phytoplankton taxa, especially the cholorophyceae Monoraphidium sp., whereas other species such as Cyclotella or Chlamydomonas sp. showed a marked increase in abundance as doses increased. However, it was not possible for the authors to determine how the three tested compounds interacted. Relyea (2009) tested a mixture of low levels (2-16 mg/L) of five herbicides (atrazine, acetolachlor, metolachlor, glyphosate, and 2,4-D) in a 36-day mesocosm experiment; results showed that phytoplankton chl a effects occurred, but, except for acetochlor, differed from those of metolachlor, glyphosate, 2,4-D, and atrazine alone. The five-herbicide mixture had similar effects on periphyton abundance as did exposure to each of the five herbicides alone.

\subsubsection{Mixtures of Herbicides with Other Organic Pesticides}

\section{- Herbicides and Insecticides}

Wendt-Rasch et al. (2003) investigated the effects of the sulfonylurea herbicide metsulfuronmethyl (1, 5 and $20 \mathrm{mg} / \mathrm{L})$ alone and in combination with the pyrethroid insecticide cypermethrin $(0.05 \mathrm{mg} / \mathrm{L})$ over a 2-week period, in freshwater enclosures. They recorded no combined direct or indirect effects of the two compounds on periphyton and phytoplankton communities. Van den Brink et al. (2009) evaluated the chronic (8 week) effects in microcosms of a mixture of the triazine herbicide atrazine and the organochlorine insecticide lindane at five equivalent concentrations, ranging from 0.01 to 5 times the EC50 of the most sensitive standard test organism (Scenedesmus subspicatum for atrazine and Oncorhynchus mykiss for lindane). Results were that phytoplankton chl a increased, following an increase in Cyclotella species, at the highest treatment rate during weeks 5 and 6 . The authors suggested 
that the effects of atrazine on phytoplankton were lower than expected and were counteracted by reduced grazing pressure from lindane-induced effects on zooplankton. Effects on periphyton were only detectable at the species level. At the highest treatment level, the effects produced were characterized as increased population density of the chlorophyceae genus Characium, and decreased population densities of the diatom genus Achnanthes and the cyanobacterium Oscillatoria redeckei. This result suggests that a cause-effect relationship existed at the highest treatment level. The authors hypothesized that the pesticide mixture affected both top-down and bottom-up regulation mechanisms.

\section{- $\underline{\text { Herbicides and Fungicides }}$}

Villeneuve et al. (2011) and Tlili et al. (2011) investigated the responses of periphytic communities to pesticide mixture exposures of the herbicide diuron and the fungicides azoxystrobin or tebuconazole, respectively. However, the main objective of these two studies was not to examine the interactions between the tested compounds. Rather, it was to assess the influence of flow regimes (Villeneuve et al. 2011) or compare chronic versus acute exposure effects (Tlili et al. 2011), using pesticide mixtures and concentrations classically encountered in a vineyard watershed. Therefore, even if the direct effects of diuron on periphytic communities were clearly detectable in the two studies, it was not possible to evaluate if simultaneous exposure to a fungicide modulated the response of the impacted communities.

\subsubsection{Successive Treatments}

One strategy to assess the fate and ecological effects of agricultural pesticide treatments is to simulate the events that often transpire to contaminate surface waters during actual pesticide application programs. The simulation procedure consists of emulating real agricultural application scenarios by making successive treatments with various pesticides to study the effects of residues leached into aquatic ecosystems. By employing ditch mesocosm studies over a period of 30 weeks, Arts et al. (2006) tested the effects of 15 separate spray treatments to potatoes with various compounds (prosulfocarb, metribuzin, lambda-cyhalothrin, chlorothalonil, fluazinam) at $0.2,1$, and $5 \%$ of the respective recommended application rates. Most effects were observed at the 5\% treatment level, which resulted in short-term changes to $\mathrm{pH}$ and oxygen levels; phytoplankton responded in a manner that was consistent with expected compound-specific results. These study results showed that the successive impact of repeated treatments by the various pesticides did not produce extensive harm, since most 
substances dissipated rapidly, avoiding simultaneous exposure for most combinations. In a similar experiment, van Wijngaarden et al. (2004) mimicked an application scenario in tulipcultivation practice. They made successive treatments of the fungicide fluazinam, the insecticide lambdacyhalothrin and the herbicides asulam and metamitron to indoor microcosms at estimated spray-drift concentrations varying from 0.2 to $5 \%$ of recommended label rates. The $0.5 \%$ treatment regime resulted in short-term effects, whereas the 2 and $5 \%$ treatment levels triggered marked effects. Although effects were detected at the ecosystem level, the two highest herbicide application levels had only minimal effects on phytoplankton and periphyton. Phytoplankton biomass increased from indirect effects; these effects resulted from the decrease of the macrophyte E. nuttallii after asulam application (decreased competition for nutrients), and from the decrease of zooplankton after lambda-cyhalothrin application (reduced grazing pressure). Treatments had no direct or indirect effects on the abundance of periphyton. Nevertheless, using the same pesticide application procedure, Wendt-Rasch et al. (2004) showed that the final effect of pesticide exposure was greatly influenced by the structure of the ecosystems. In mesotrophic microcosms, dominated by submerged macrophytes, periphyton biomass increased and species composition varied at the $0.5 \%$ treatment level and higher. However, there was no effect on these two parameters in eutrophic microcosms, characterized by a high Lemna surface coverage.

\section{Field Studies}

\subsection{Effects of of In Situ Exposure on Community Structure and Primary Production}

Lotic ecosystems, especially in agricultural areas, are often highly exposed to herbicide pollution. A common way to assess the resulting effects on aquatic communities is to compare biological parameters at different sampling sites that received different herbicide levels (ideally including a clean reference point). This strategy was successfully used by Dorigo et al. (2002) to measure changes to phytobenthic community species composition in river sections, mainly contaminated by atrazine and isoproturon. Using partial $18 \mathrm{~S}$ rRNA cloning and sequencing, they showed that the proportion of diatoms was lower at the unpolluted site than at polluted ones. In an agricultural area, Pesce et al. (2008) observed a sharp drop in free algal biomass during the main pollution period, which suggested a strong herbicide impact on phototrophic communities. However, Dorigo et al. (2002) and Pesce et al. (2008) urged caution in interpreting these results, because of the complexity in distinguishing between 
effects of pollutants vs. other environmental variables. Morin et al. (2009) have also recently stressed the difficulties in accurately linking diatom community structure to pesticide inputs in lotic environments. However, Ricart et al. (2010) revealed a potential relationship between triazine-type herbicides and diatom community distribution in a contaminated river (Llobregat river, Spain). Their study also showed that the metrics most sensitive to the presence of pesticides were chl a and photosynthetic activity.

A series of in situ studies have recently been conducted in a small river that drains a vineyard watershed (Morcille River, France; Montuelle et al. 2010). Various surveys revealed that biofilm phototrophic community composition varied from upstream to downstream locations, in parallel with increased nutrient and pesticide concentrations. Changes in phototrophic community composition along this river have been recorded using several end points: pigment distribution, eukaryotic gene structure, and diatom taxonomic composition (Dorigo et al. 2007, 2009, 2010a, b; Morin et al. 2010; Pesce et al. 2010a, b).

\subsection{PICT Approaches}

Among the various methods and tools available to evaluate microbial community responses to toxicant exposure, the PICT approach makes it possible to partially isolate the effects of individual toxicants within an ecosystem that is subjected to multiple stressors, by studying shifts in community sensitivity (Schmitt-Jansen et al. 2008). In the river Morcille, PICT was, therefore, applied to verify that structural changes in phototrophic communities were related to pesticide contamination. In all surveys, all biofilms exhibited an upstream-to-downstream increase in tolerance to diuron, which is the most often detected herbicide in this river (Dorigo et al. 2007, 2009, 2010a, b; Pesce et al. 2010a, b). Pesce et al. (2010a) identified three possible influences that constituted covarying environmental variables (i.e., nitrates, conductivity, and temperature) in the tolerance induction. However, statistical analysis demonstrated that the main factor affecting diuron sensitivity was the mean in situ diuron exposure level during the biofilm colonization periods.

Nevertheless, field studies conducted by Guasch et al. (1998a, b, 2003) in various European streams and rivers clearly indicated that the sensitivity of phototrophic biofilms to organic herbicides in lotic systems may be highly dependent on light conditions during colonization. Indeed, they observed higher atrazine toxicity to natural biofilms that were adapted to highlight conditions, and were dominated by green algae or cyanobacteria, than that to diatomdominated biofilms adapted to low-light conditions. 
Dorigo et al. (2004) assessed seasonal changes in the sensitivity of river microalgae to atrazine and isoproturon along a contamination gradient, and showed that both free and fixed algal communities responded positively to the PICT approach. The positive response occurred despite the fact that free algae are mobile and can reduce their exposure time to toxicants by escaping from adverse situations. Both periphyton and phytoplankton can also be used to run PICT approaches in lake ecosystems, as shown by Nyström et al. (2002) and Bérard et al. (2003), who assessed the toxic effects of Irgarol 1051 and/or atrazine on microalgal communities in Lake Geneva.

\subsection{Recovery Studies}

In only a few, more recently performed studies have researchers examined recovery processes of phototrophic communities, following herbicide exposure under natural river contamination conditions (Dorigo et al. 2010a, b; Morin et al. 2010; Rotter et al. 2011). The authors of these four studies have attempted to characterize the dynamics of recovery of periphytic communities transplanted from herbicide-contaminated sites to "nonpolluted" reference sites. The recovery processes were evaluated for changes in community structure (biomass, distribution of algal classes), diversity (diatom taxonomic composition, 18S PCR-DGGE band patterns) and tolerance capacities, using PICT-approaches for the most predominant herbicide in the studied rivers (i.e., diuron in Dorigo et al. 2010a, b and prometryn in Rotter et al. 2011). The results indicated a high recovery potential for periphytic communities. Evidence supported the view that communities recovered, at least partially, in structural, diversity, and functional attributes, after a few weeks within reference sites. Accordingly, Dorigo et al. (2010a, b) and Rotter et al. (2011) emphasized that the use of biofilm recovery capacity could potentially be a suitable management tool for analysis of recovery processes in freshwater ecosystems, especially when using the PICT-concept. However, Morin et al. (2010) emphasized that immigration and emigration of algal species certainly takes place in such transplantation experiments. Therefore, the observed trajectories of recovery were probably assisted by such species migration, rather than resulting only from the new exposure conditions at transplantation sites.

\section{Potential Future Areas for Research}

Among many future areas of research, three main promising ones have been identified: 
- Improvement of exposure characterization, and improved measurement of bioavailable contaminant concentrations

- Improvement or diversification of effects characterization from individual to the community level

- Assessment of environmental restoration and ecological trajectories after removal of toxic pressure

\subsection{Improving Exposure Assessments}

\subsubsection{The Question of Mixtures}

Despite the fact that pesticides frequently occur in mixtures, our review clearly shows a dearth of studies that evaluate pesticide mixture effects on autotrophic microbial communities. Even fewer mixture studies have been performed under environmentally relevant conditions. This point has recently been emphasized by Van den Brink et al. (2009), who noted the scarcity of data on community-level effects of pesticide mixtures. Several authors have emphasized the need to consider mixtures, when assessing the ecological effects of pesticides (Chèvre et al. 2006; Knauer et al. 2010). However, there is still debate over the best way to address this issue (Knauert et al. 2008, 2009), and it can be argued that the assessment of mixture effects is in its infancy (Belden et al. 2007). DeLorenzo et al. (2001) emphasized the need to address the toxicity of pesticide degradation products to aquatic microorganisms. The integration into risk assessments of the effects shown by pesticide metabolites, both alone and in pesticide mixtures, would significantly improve ecological risk assessment processes (Sinclair and Boxall 2003). Unfortunately, there is still too little research of this type being performed. Another progressive step will be to take into account the mode of action of pesticides, since mechanistic insights may help explain the toxicity of mixtures (additivity or independence of action; Chèvre et al. 2006; Ricart 2011).

\subsubsection{Benefiting from the Development of Chemical Tools}

Another area in which progress is needed is development of better chemical sensing and field sampling devices. The recent development of passive sampling techniques for monitoring organic pesticides in freshwaters (e.g., polar organic chemical integrative samplers, diffusive gradients in thin films, semipermeable membrane devices, silicon rods, etc.) opens new avenues to screen for a large variety of organic and inorganic contaminants. Such improvements would facilitate the assessment of the relationship between community-level 
tolerance induction and mean contaminant exposure (Pesce et al. 2010b; Rotter et al. 2011). Moreover, recently, some authors have proposed combining passive samplers with bioassays to assess the toxicity of toxicant mixtures extracted directly from the environment. This combination method may constitute a simple and cost-effective way to determine potential acute effects of contaminant mixtures in various aquatic environments (e.g., Muller et al. 2007; Liscio et al. 2009; Shaw et al. 2009). Recently, polar organic samplers have been combined with photosynthesis bioassays (using microalgae cultures) to assess phytotoxicity of various mixtures of organic toxicants (Escher et al. 2006; Muller et al. 2007; Shaw et al. 2009). The use of natural phototrophic microbial communities in such an approach could improve outcomes and usefulness of previous results, which combined polar organic samplers with monospecific photosynthesis bioassays (Pesce et al. 2011).

\subsubsection{Exposure Characteristics and Dynamics (Chronic-Acute)}

The question whether there is a relevant exposure measure for periphytic microorganisms that are embedded in an ExoPolySaccharide (EPS) matrix is open: depending on the solubility of pesticides, the concentrations in the water phase may not be the most useful for predicting biological effects. Rather, periphytic assemblage studies should address exposure, by focusing on biofilm-adsorbed pesticide concentrations, especially for hydrophobic compounds. Indeed, the sorption of pesticides on periphyton can enhance toxicity by extending exposure time (Dorigo et al. 2010a). Pesticide sorption also drives bioaccumulation processes by favoring pesticide transfer to higher trophic levels via periphyton consumers, such as grazers.

Exposures are naturally dynamic and comparing the consequences of long-term low-dose (i.e., chronic exposure) vs. short-term high-dose (i.e., acute exposure) exposures is very difficult to accomplish. Recent chemical monitoring studies have shown that, during floods, many pollutant fluxes - including those of pesticides - can vary over several orders of magnitude, especially in small stream systems (Rabiet et al. 2009). In small stream ecosystems, environmental exposure of aquatic communities to pesticides can rapidly increase during rainfall events. Therefore, special attention should be given to (a) studying pulsedexposures that result from episodic runoff events and (b) addressing the ecotoxicological question of how to predict the lethal and sublethal consequences of such population exposures (Tlili et al. 2008, 2011). Furthermore, the effect of long-term, low-dose pesticide exposures may produce effects (e.g., biodiversity changes, tolerance acquisition, and functional changes) that only become apparent in organisms after several generations. 


\subsection{Improving Assessment of Biological Effects}

\subsubsection{From Monospecific Tests to Community Assessment}

There have long been efforts to enhance the integration of ecology and ecotoxicology. However, it is now well established that a more suitable model than single-species testing is to assess the ecological effects of pesticides at the microbial community level. Nevertheless, data from monospecific bioassays will also be required. Hence, the SSD approach has become a practical ecological risk assessment method and decision-making processes to determine water quality criteria (Schmitt-Jansen and Altenburger 2005b). Although SSD approaches are useful in environmental risk research (Schmitt-Jansen et al. 2008), especially if toxicity datasets are sufficiently robust (Schmitt-Jansen and Altenburger 2005a), they cannot fully replace model ecosystems (microcosms, mesocosms, or enclosures) or field investigations. The reason is that SSD approaches focus on short-term or midterm effects and tend to ignore important ecological factors (Brock et al. 2004), such as the indirect effects that result from community interactions (i.e., interactions among zooplankton, benthic grazers, heterotrophic microbial communities, etc.).

\subsubsection{Using Molecular Tools in Ecotoxicology}

Although molecular biology has revolutionized the understanding of microbial ecology in various environments, including water ecosystems, its use in ecotoxicology has probably been underused, although we did find a few studies that employed molecular techniques such as PCR-DGGE (e.g., Dorigo et al. 2007; Tlili et al. 2008; Pesce et al. 2009) or 18S rRNA cloning and sequencing (Dorigo et al. 2002). New sets of 18S rRNA primers that are more specific to different taxonomic levels (e.g., Chlorophycea and Bacillariophyceae; Valiente Moro et al. 2009) could prove to be highly valuable for studying the phototrophic community dynamics, after pesticide exposure. Cutting-edge molecular tools such as (meta)genomics or microarrays also offer new and powerful possibilities for assessing pesticide effects on microbial community (including phototrophic communities) diversity and functionality.

\subsubsection{Understanding the Ecological Consequences of Tolerance Acquisition}

For many research scientists the only realistic approach to obtain aquatic ecotoxicology data consists of performing in situ studies (Boudou and Ribeyre 1997). Field studies, however, may yield more useful results, although distinguishing between pollutant effects and those related to other physical, chemical or biological environmental variables can be very challenging. As mentioned above (Sect. 3), PICT is one of the tools best adapted to achieve 
this goal because tolerance to one toxicant is less sensitive than is other community characteristics to natural variations at sampling sites (Schmitt-Jansen et al. 2008). To improve PICT methodology, special attention should be paid to cotolerance patterns and to developing new short-term tests designed to evaluate tolerance capacities, especially with a view to broadening the range of toxicants monitored (Blanck 2002; Tlili and Montuelle 2011).

\subsection{Ecosystem Recovery}

Finally, interest in restoring chemically polluted ecosystems is growing, especially through environmental policies such as the European Water Framework Directive (EU 2000). In this Directive, the EU commits its members to achieve good qualitative and quantitative ecological status of all surface waters, and there is now growing interest in studying recovery trajectories. Ecosystem recovery is defined as the potential for a disturbed ecosystem to return to a state similar to that before a stress was imposed on it, which basically revolves around the notion of ecosystem and community resilience. Despite the importance of studying and understanding the resilience processes employed by autotrophic microbial communities following pesticide exposure, even basic knowledge on these processes remains scarce (e.g., Morin et al. 2010; Dorigo et al. 2010a, b; Rotter et al. 2011).

\section{Summary}

Over the past 15 years, significant research efforts have been channeled into assessing the effects of organic herbicides on freshwater phototrophic microbial communities. The results of this research are reviewed herein. The main conclusions we have reached after performing this review can be summarized into five points:

- Most relevant assessments have dealt with the effects of triazine and phenylurea herbicides. Herbicides from these chemical classes are often considered to be model compounds when photosystem-II inhibitors are studied.

- Until the early 2000s, the vast majority of investigations conducted to evaluate herbicide effects on phototropic microbes were performed in microcosms or mesocosms. In such studies, herbicides were usually applied alone, and often at concentrations much higher than those detected in the environment. More recently, the trend has been toward more realistic and relevant studies, in which lower herbicide concentrations were considered, and compound mixtures or successive treatments were tested. Increasingly, in situ studies are being designed to directly evaluate 
microbial community responses, following chemical exposures in contaminated aquatic environments.

- Several biological end points are used to evaluate how organisms in the phototrophic microbial community respond to herbicide exposure. These end points allow the detection of quantitative changes, such as chl a concentrations, total cell counts or periphytic biomass, qualitative changes such as community structure to algal diversity, or functional changes such as photosynthesis and respiration, among others. They may give different and complementary information concerning the responses of microbial communities.

- PICT approaches, which have generally combined functional and structural measurements, may prove to be valuable for assessing both an immediate impact, and for factoring in the contamination history of an ecosystem at the community level.

- Finally, any relevant assessment of pesticide effects should incorporate a detailed environmental characterization that would include abiotic parameters (light, flow speed, nutrient content), or biotic parameters (diversity and structure of biofilms), because these control the bioavailability of pesticides, and thereby the exposure of microbial communities.

To improve the value of ecotoxicological risk assessments, future research is needed in two key areas: first, more information on the effects of pollutants at the community level must be obtained (new tools and new end points), and second, more effort must be directed to reinforce the ecological relevance of toxicological investigations.

\section{Acknowledgments}

This work received funding from the French National Office for the Aquatic Environment (ONEMA-CEMAGREF agreement 2010, action 26 "Remédiation de l'effet de pesticides," and ONEMA-INRA agreement 2010, action D1-2 "Des bioindicateurs pour évaluer l'impact ou la restauration vis à vis des pesticides") and the IMPALAC Project (Impact of Pesticides on Lakes), backed by the Ministry of Ecology and Sustainable Development (MEDDTL). The authors also thank David Whitacre for helpful suggestions and comments on earlier drafts of the manuscript. 


\section{References}

Abdel-Hamid MI, Källqvist T, Hessen DO, Berge D (1996) The use of field enclosure experiments to study the effect of pesticides on lake phytoplankton. Lakes Reserv Res Manag 2: 199-209.

Arts GHP, Buijse-Bogdan LL, Belgers JDM, van Rhenen-Kersten CH, van Wijngaarden RPA, Roessink I, Maund SJ, van den Brink PJ, Brock TCM (2006) Ecological impact in ditch mesocosms of simulated spray drift from a crop protection program for potatoes. Integr Environ Assess Manag 2: 105-125.

Belden JB, Gilliom RJ, Lydy MJ (2007). How well can we predict the toxicity of pesticide mixtures to aquatic life? Integr Environ Assess Manag 3: 364-372.

Bérard A, Leboulanger C, Pelte T (1999a) Tolerance of Oscillatoria limnetica Lemmermann to atrazine in natural phytoplankton populations and in pure culture: influence of season and temperature. Arch Environ Contam Toxicol 37: 472-479.

Bérard A, Pelte T, Druart JC (1999b) Seasonal variations in the sensitivity of Lake Geneva phytoplankton community structure to atrazine. Arch Hydrobiol 145: 277-295.

Bérard A, Benninghoff C (2001) Pollution-induced community tolerance (PICT) and seasonal variations in the sensitivity of phytoplankton to atrazine in nanocosms. Chemosphere 45 : $427-437$.

Bérard A, Dorigo U, Mercier I, Becker-van Slooten K, Grandjean D, Leboulanger C (2003) Comparison of the ecotoxicological impact of the triazines Irgarol 1051 and atrazine on microalgal cultures and natural microalgal communities in Lake Geneva. Chemosphere 53: 935-944.

Blanck H (2002) A critical review of procedures and approaches used for assessing pollutioninduced community tolerance (PICT) in biotic communities. Hum Ecol Risk Assess 8: 1003-1034.

Boudou A, Ribeyre F (1997) Aquatic ecotoxicology: From the ecosystem to the cellular and molecular levels. Environ Health Persp 105: 21-35.

Brock TCM, Crum SJH, Deneer JW, Heimbach F, Roijackers RMM, Sinkeldam JA (2004) Comparing aquatic risk assessment methods for the photosynthesis-inhibiting herbicides metribuzin and metamitron. Environ Pollut 130: 403-426.

Brown LS, Lean DRS (1995) Toxicity of selected pesticides to lake phytoplankton measured using photosynthetic inhibition compared to maximal uptake rates of phosphate and ammonium. Environ Toxicol Chem 14: 93-98. 
Caquet T, Deydier-Stephan L, Lacroix G, Le Rouzic B, Lescher-Moutoué F (2005) Effects of fomesafen, alone and in combination with an adjuvant, on plankton communities in freshwater outdoor pond mesocosms. Environ Toxicol Chem 24: 1116-1124.

Carder JP, Hoagland KD (1998) Combined effects of alachlor and atrazine on benthic algal communities in artificial streams. Environ Toxicol Chem 17: 1415-1420.

Chang KH, Sakamoto M, Ha JY, Miyabara Y, Nakano SI, Doi H, Hanazato T (2011) Response of the plankton community to herbicide application (triazine herbicide, simetryn) in a eutrophicated system: short-term exposure experiment using microcosms. Limnology 12: 11-16.

Chapman PM (2002) Integrating toxicology and ecology: putting the "eco" into ecotoxicology. Mar Pollut Bull 44: 7-15.

Chèvre N, Loepfe C, Singer H, Stamm C, Fenner K, Escher BI (2006) Including mixtures in the determination of water quality criteria for herbicides in surface water. Environ Sci Technol 40: 426-435.

Clements WH, Rohr JR (2009) Community responses to contaminants: using basic ecological principles to predict ecotoxicological effects. Environ. Toxicol. Chem. 28: 1789-1800.

Couderchet M, Schmalfuss J, Böger P (1998) A specific and sensitive assay to quantify the herbicidal activity of chloroacetamides. Pestic Sci 52: 381-387.

Daam MA, Van den Brink PJ (2007) Effects of chlorpyrifos, carbendazim and linuron on the ecology of a small indoor aquatic microcosm. Arch Environ Contam Toxicol 53: 22-35.

Daam MA, Rodrigues AMF, Van den Brink PJ, Nogueira AJA (2009a) Ecological effects of the herbicide linuron in tropical freshwater microcosms. Ecotoxicol Environ Safe 72: 410-423.

Daam MA, Van den Brink PJ, Nogueira AJA (2009b) Comparison of fate and ecological effects of the herbicide linuron in freshwater model ecosystems between tropical and temperate regions. Ecotoxicol Environ Safe 72: 424-433.

Debenest T, Pinelli E, Coste M, Silvestre J, Mazzella N, Madigou C, Delmas F (2009) Sensitivity of freshwater periphytic diatoms to agricultural herbicides. Aquat Toxicol 93: $11-17$.

DeLorenzo ME, Scott GI, Ross PE (1999) Effects of the agricultural pesticides atrazine, deeethylatrazine, endosulfan, and chlorpyrifos on an estuarine microbial food web. Environ Toxicol Chem 18: 2824-2835.

DeLorenzo ME, Scott GI, Ross PE (2001) Toxicity of pesticides to aquatic microorganisms: A review. Environ Toxicol Chem 20: 84-98. 
Detenbeck NE, Hermanutz R, Allen K, Swift MC (1996) Fate and effects of the herbicide atrazine in flow-through wetland mesocosms. Environ Toxicol Chem 15: 937-946.

Devault DA, Merlina G, Lim P, Probst JL, Pinelli E (2007) Multi-residues analysis of preemergence herbicides in fluvial sediments: application to the mid-Garonne River. J Environ Monit 9: 1009-1017.

Dorigo U, Bérard A, Humbert JF (2002) Comparison of eukaryotic phytobenthic community composition in a polluted river by partial $18 \mathrm{~S}$ rRNA gene cloning and sequencing. Microb Ecol 44: 372-380.

Dorigo U, Bourrain X, Bérard A, Leboulanger C (2004) Seasonal changes in the sensitivity of river microalgae to atrazine and isoproturon along a contamination gradient. Sci Total Environ 318: 101-114.

Dorigo U, Leboulanger C, Bérard A, Bouchez A, Humbert JF, Montuelle B (2007) Lotic biofilm community structure and pesticide tolerance along a contamination gradient in a vineyard area. Aquat Microb Ecol 50: 91-102.

Dorigo U, Lefranc M, Leboulanger C, Montuelle B, Humbert JF (2009) Spatial heterogeneity of periphytic microbial communities in a small pesticide-polluted river. FEMS Microbiol Ecol 67: 491-501.

Dorigo U, Bérard A, Rimet F, Bouchez A, Montuelle B (2010a) In situ assessment of periphytonrecovery in a river contaminated by pesticides. Aquat Toxicol 98: 396-406.

Dorigo U, Bérard A, Bouchez A, Rimet F, Montuelle B (2010b) Transplantation of microbenthic algal assemblages to assess structural and functional recovery after diuron exposure. Arch Environ Contam Toxicol 59: 555-563.

Downing HF, DeLorenzo ME, Fulton MH, Scott GI, Madden CJ, Kucklick JR (2004) Effects of the agricultural pesticides atrazine, chlorothalonil, and endosulfan on South Florida microbial assemblages. Ecotoxicology 13: 245-260.

Escher BI, Quayle P, Muller R, Schreiber U, Mueller JF (2006) Passive sampling of herbicides combined with effect analysis in algae using a novel high-throughput phytotoxicity assay (Maxi-Imaging-PAM). J Environ Monit 8: 456-464.

EU (2000) Directive 2000/60/EC of the European parliament and of the council establishing a framework for Community action in the field of water policy. European Parliament, The Council, PE-CONS 3639/1/00 REV 1 EN.

Faber MJ, Thompson DG, Stephenson GR, Boermans HJ (1998) Impact of glufosinateammonium and bialaphos on the phytoplankton community of a small eutrophic northern lake. Environ Toxicol Chem 17: 1282-1290. 
Fairchild JF, Sappington LC (2002) Fate and effects of the triazinone herbicide metribuzin in experimental pond mesocosms. Arch Environ Contam Toxicol 43: 198-202.

Faust M, Altenburger R, Boedecker W, Grimme LH (1994) Algal toxicity of binary combinations of pesticides. Bull Environ Contam Toxicol 53: 134-141.

Faust M, Altenburger R, Backhaus T, Blanck H, Boedeker W, Gramatica P, Hamer V, Scholze M, Vighi M, Grimme LH (2001) Predicting the joint algal toxicity of multicomponent s-triazine mixtures at low-effect concentrations of individual toxicants. Aquat Toxicol 56: 13-32.

Filser J (2008) Ecotoxicology and ecosystems: Relevance, restrictions, research needs. Basic Appl Ecol 9: 333-336.

Francoeur SN, Johnson AC, Kuehn KA, Neely RK (2007) Evaluation of the efficacy of the photosystem II inhibitor DCMU in periphyton and its effects on nontarget microorganisms and extracellular enzymatic reactions. J N Am Benthol Soc 26: 633-641.

Geiszinger A, Bonnineau C, Faggiano L, Guasch H, Lopez-Daval J, Proia L, Ricart M, Ricciardi F, Romaní A, Rotter S, Muñoz I, Schmitt-Jansen M, Sabater S (2009). The relevance of the community approach linking chemical and biological analyses in pollution assessment. Trends Anal Chem 28: 619-626.

Gilliom RJ (2007) Pesticides in U.S. streams and groundwater. Environ Sci Technol 15: 3409-3414.

Gruessner B, Watzin MC (1996) Response of aquatic communities from a Vermont stream to environmentally realistic atrazine exposure in laboratory microcosms. Environ Toxicol Chem 15: 410-419.

Guasch H, Ivorra N, Lehmann V, Paulsson M, Real M, Sabater S (1998a) Community composition and sensitivity of periphyton to atrazine in flowing waters: The role of environmental factors. J Appl Phycol 10: 203-213.

Guasch H, Sabater S (1998b) Light history influences the sensitivity to atrazine in periphytic algae. J Phycol 34: 233-241.

Guasch H, Admiraal W, Sabater S (2003) Contrasting effects of organic and inorganic toxicants on freshwater periphyton. Aquat Toxicol 64: 165-175.

Guasch H, Lehmann V, van Beeusekom B, Sabater S, Admiraal W (2007) Influence of phosphate on the response of periphyton to atrazine exposure. Arch Environ Contam Toxicol 52: 32-37.

Gustavson K, Wängberg SÅ (1995) Tolerance induction and succession in microalgae communities exposed to copper and atrazine. Aquat Toxicol 32: 283-302. 
Gustavson K, Møhlenberg F, Schlüter L (2003) Effects of exposure duration of herbicides on natural stream periphyton communities and recovery. Arch Environ Contam Toxicol 45: $48-58$.

Hartgers EM, Aalderink GHR, Van den Brink PJ, Gylstra R, Wiegman JWF, Brock TCM (1998) Ecotoxicological threshold levels of a mixture of herbicides (atrazine, diuron and metolachlor) in freshwater microcosms. Aquat Ecol 32: 135-152.

Junghans M, Backhaus T, Faust M, Scholze M, Grimme LH (2003) Predictability of combined effects of eight chloroacetanilide herbicides on algal reproduction. Pest Manag Sci 59: 1101-1110.

Jüttner I, Peither A, Lay JP, Kettrup A, Ormerod SJ (1995) An outdoor mesocosm study to assess ecotoxicological effects of atrazine on a natural plankton community. Arch Environ Contam Toxicol 29: 435-441.

Kasai F, Hanazato T (1995a) Effects of the triazine herbicide, simetryn, on freshwater plankton communities in experimental ponds. Environ Pollut 89: 197-202.

Kasai F, Hanazato T (1995b) Genetic changes in phytoplankton communities exposed to the herbicide simetryn in outdoor experimental ponds. Arch Environ Contam Toxicol 28: $154-160$.

Knauer K, Leimgruber A, Hommen U, Knauert S (2010) Co-tolerance of phytoplankton communities to photosynthesis II inhibitors. Aquat Toxicol 96: 256-263.

Knauert S, Escher B, Singer H, Hollender J, Knauer K (2008) Mixture toxicity of three photosystem II inhibitors (atrazine, isoproturon, and diuron) toward photosynthesis of freshwater phytoplankton studied in outdoor mesocosms. Environ Sci Technol 42: 64246430.

Knauert S, Dawo U, Hollender J, Hommen U, Knauer K (2009) Effects of photosystem II inhibitors and their mixture on freshwater phytoplankton succession in outdoor mesocosms. Environ Toxicol Chem 28: 836-845.

Kobraei ME, White DS (1996) Effects of 2,4-dichlorophenoxyacetic acid on Kentucky algae: simultaneous laboratory and field toxicity testings. Arch Environ Contam Toxicol 31: $571-580$.

Laviale M, Prygiel J, Créach A (2010) Light modulated toxicity of isoproturon toward natural stream periphyton photosynthesis: a comparison between constant and dynamic light conditions. Aquat Toxicol 97: 334-342.

Leboulanger C, Bouvy M, Carré C, Cecchi P, Amalric L, Bouchez A, Pagano M, Sarazin G (2011) Comparison of the effects of two herbicides and an insecticide on tropical 
freshwater plankton in microcosms. Arch Environ Contam Toxicol DOI 10.1007/s00244011-9653-3

Leboulanger C, Rimet F, Hème de Lacotte M, Bérard A (2001) Effects of atrazine and nicosulfuron on freshwater microalgae. Environ Pollut 26: 131-135.

Liscio C, Magi E, Di Carro M, Suter MJF, Vermeirssen ELM (2009) Combining passive samplers and biomonitors to evaluate endocrine disrupting compounds in a wastewater treatment plant by LC/MS/MS and bioassay analyses. Environ Pollut 157: 2716-2721.

López-Doval JC, Ricart M, Guasch H, Romaní AM, Sabater S, Muñoz I (2010) Does grazing pressure modify diuron toxicity in a biofilm community? Arch Environ Contam Toxicol 58: 955-962.

McClellan K, Altenburger R, Schmitt-Jansen M (2008) Pollution-induced community tolerance as a measure of species interaction in toxicity assessment. J Appl Ecol 45: 15141522.

Mohr S, Schröder H, Feibicke M, Berghahn R, Arp W, Nicklisch A (2008a) Long-term effects of the antifouling booster biocide irgarol 1051 on periphyton, plankton and ecosystem function in freshwater pond mesocosms. Aquat Toxicol 90: 109-120.

Mohr S, Feibicke M, Berghahn R, Schmiediche R, Schmidt R (2008b). Response of plankton communities in freshwater pond and stream mesocosms to the herbicide metazachlor. Environ Pollut 152: 530-542.

Montuelle B, Dorigo U, Bérard A, Volat B, Bouchez A, Tlili A, Gouy V, Pesce S (2010) The periphyton as a multimetric bioindicator for assessing the impact of land use on rivers: an overview of the Ardières-Morcille experimental watershed (France). Hydrobiologia 657: $123-141$.

Morin S, Bottin M, Mazzella N, Macary F, Delmas F, Winterton P, Coste M (2009) Linking diatom community structure to pesticide input as evaluated through a spatial contamination potential (Phytopixal): a case study in the Neste river system (South-West France). Aquat Toxicol 94: 28-39.

Morin S, Pesce S, Tlili A, Coste M, Montuelle B (2010) Recovery potential of periphytic communities in a river impacted by a vineyard watershed. Ecol Indic 10: 419-426.

Muller R, Tang JYM, Thier R, Mueller JF (2007). Combining passive sampling and toxicity testing for evaluation of mixtures of polar organic chemicals in sewage treatment plant effluent. J Environ Monit 9: 104-109.

Muñoz I, Real M, Guasch H, Navarro E, Sabater S (2001) Effects of atrazine on periphyton under grazing pressure. Aquat Toxicol 55: 239-249. 
Noack U, Geffke T, Balasubramanian R, Papenbrock J, Braune M, Scheerbaum D (2003) Effects of the herbicide metazachlor on phytoplankton and periphyton communities in outdoor mesocosms. Acta Hydrochim Hydrobiol 31: 482-490.

Nyström B, Paulsson M, Almgren K, Blanck H (2000) Evaluation of the capacity for development of atrazine tolerance in periphyton from a Swedish freshwater site as determined by inhibition of photosynthesis and sulfolipid synthesis. Environ Toxicol Chem 19: 1324-1331.

Nyström B, Becker-Van Slooten K, Bérard A, Grandjean D, Druart JC, Leboulanger C (2002) Toxic effects of Irgarol 1051 on phytoplankton and macrophytes in Lake Geneva. Water Res 36: 2020-2028.

Pannard A, Le Rouzic B, Binet F (2009) Response of phytoplankton community to low-dose atrazine exposure combined with phosphorus fluctuations. Arch Environ Contam Toxicol 57: 50-59.

Pearson N, Crossland NO (1996) Measurement of community photosynthesis and respiration in outdoor artificial streams. Chemosphere 32: 913-919.

Pérès F, Florin D, Grollier T, Feurtet-Mazel A, Coste M, Ribeyre F, Ricard M, Boudou A (1996) Effects of the phenylurea herbicide isoproturon on periphytic diatom communities in freshwater indoor microcosms. Environ Pollut 94: 141-152.

Pérez GL, Torremorell A, Mugni H, Rodriguez P, Solange Vera M, do Nascimento M, Allende L, Bustingorry J, Escaray R, Ferraro M, Izaguirre I, Pizarro H, Bonetto C, Morris DP, Zagarese H (2007) Effects of the herbicide Roundup on freshwater microbial communities: a mesocosm study. Ecol Appl 17: 2310-2322.

Perschbacher PW, Stone N, Ludwig GM, Guy Jr CB (1997) Evaluation of effects of common aerially-applied soybean herbicides and propanil on the plankton communities of aquaculture ponds. Aquaculture 157: 117-122.

Perschbacher PW, Ludwig GM, Slaton N (2002) Effects of common aerially-applied rice herbicides on the plankton communities of aquaculture ponds. Aquaculture 214: 241-246.

Perschbacher PW, Ludwig GM (2004) Effects of diuron and other aerially-applied cotton herbicides and defoliants on the plankton communities of aquaculture ponds. Aquaculture 233: 197-203.

Perschbacher PW, Ludwig GM, Edziyie R (2008) Effects of atrazine drift on production pond plankton communities and water quality using experimental mesocosms. J World Aquacult Soc 39: 126-130. 
Pesce S, Fajon C, Bardot C, Bonnemoy F, Portelli C, Bohatier J (2006) Effects of the phenylurea herbicide diuron on natural riverine microbial communities in an experimental study. Aquat Toxicol 78: 303-314.

Pesce S, Fajon C, Bardot C, Bonnemoy F, Portelli C, Bohatier J (2008) Longitudinal changes in microbial planktonic communities of a French river in relation to pesticide and nutrient inputs. Aquat Toxicol 86: 352-360.

Pesce S, Batisson A, Bardot C, Fajon C, Portelli C, Montuelle B, Bohatier J (2009) Response of spring and summer riverine microbial communities following glyphosate exposure. Ecotoxicol Environ Saf 72: 1905-1912.

Pesce S, Margoum C, Montuelle B (2010a) In situ relationships between spatio-temporal variations in diuron concentrations and phototrophic biofilm tolerance in a contaminated river. Water Res 44: 1941-1949.

Pesce S, Lissalde S, Lavieille D, Margoum C, Mazzella N, Roubeix V, Montuelle B (2010b) Evaluation of single and joint toxic effects of diuron and its main metabolites on natural phototrophic biofilms using a pollution-induced community tolerance (PICT) approach. Aquat Toxicol 99: 492-499.

Pesce S, Morin S, Lissalde S, Montuelle B, Mazzella N (2011) Combining polar organic chemical integrative samplers (POCIS) with toxicity testing to evaluate pesticide mixture effects on natural phototrophic biofilms. Environ Pollut 159: 735-741.

Pinckney JL, Örnólfsdóttir EB, Lumsden E (2002) Estuarine phytoplankton group-specific responses to sublethal concentrations of the agricultural herbicide, atrazine. Mar Pollut Bull 44: 1109-1116.

Pollehne F, Jost G, Kerstan E, Meyer-Harms B, Reckerman M, Nausch M, Wodarg D (1999) Triazine herbicides and primary pelagic interactions in an estuarine summer situation. $\mathrm{J}$ Exp Mar Biol Ecol 238: 243-257.

Rabiet M, Margoum C, Gouy V, Carluer N, Coquery M (2009) Assessing pesticide concentration dynamics and fluxes in the stream of a small vineyard watershed - Effect of sampling strategy. Environ Pollut 158: 737-748.

Relyea RA (2005) The impact of insecticides and herbicides on the biodiversity and productivity of aquatic communities. Ecol Appl 15: 618-627.

Relyea R, Hoverman J (2006) Assessing the ecology in ecotoxicology: a review and synthesis in freshwater systems. Ecol Lett 9: 1157-1171.

Relyea RA (2009) A cocktail of contaminants: how mixtures of pesticides at low concentrations affect aquatic communities. Oecologia 159: 363-376. 
Ricart M (2011) Effects of priority and emerging pollutants on river biofilms, phD Thesis, University of Girona, Spain, 202 p.

Ricart M, Barceló D, Geiszinger A, Guasch H, Alda MLD, Romaní AM, Vidal G, Villagrasa M, Sabater S (2009) Effects of low concentrations of the phenylurea herbicide diuron on biofilm algae and bacteria. Chemosphere 76: 1392-1401.

Ricart M, Guasch H, Barceló D, Brix R, Conceição MH, Geiszinger A, López de Alda MJ, López-Doval JC, Muñoz I, Postigo C, Romaní AM, Villagrasa M, Sabater S (2010) Primary and complex stressors in polluted Mediterranean rivers: Pesticide effects on biological communities. J Hydrol 383: 52-61.

Rohr JR, Crumrine PW (2005) Effects of an herbicide and an insecticide on pond community structure and processes. Ecol Appl 15: 1135-1147.

Rotter S, Sans-Piché F, Streck G, Altenburger R Schmitt-Jansen M (2011) Active biomonitoring of contamination in aquatic systems - An in situ translocation experiment applying the PICT concept. Aquat Toxicol 101, 228-236.

Sánchez P, Kubitza J, Dohmen GP, Tarazona JV (2006) Aquatic risk assessment of the new rice herbicide profoxydim. Environ Pollut 142, 181-189.

Schaffer JD, Sebetich MJ (2004) Effects of aquatic herbicides on primary productivity of phytoplankton in the laboratory. Bull Environ Contam Toxicol 72: 1032-1037.

Schmitt-Jansen M, Altenburger R (2005a) Predicting and observing responses of algal communities to photosystem II-herbicide exposure using pollution-induced community tolerance and species-sensitivity distributions. Environ Toxicol Chem 24: 304-312.

Schmitt-Jansen M, Altenburger R (2005b) Toxic effects of isoproturon on periphyton communities - a microcosm study. Estuar Coast Shelf Sci 62: 539-545.

Schmitt-Jansen M, Altenburger R (2008) Community-level microalgal toxicity assessment by multiwavelength-excitation PAM fluorometry. Aquat Toxicol 86: 49-58.

Schmitt-Jansen M, Veit U, Dudel G, Altenburger R (2008) An ecological perspective in aquatic ecotoxicology: Approaches and challenges. Basic Appl Ecol 9: 337-345.

Schneider J, Morin A, Pick FR (1995) The response of biota in experimental stream channels to a 24-hour exposure to the herbicide Velpar L®. Environ Toxicol Chem 14, 1607-1613.

Schuler LJ, Rand GM (2008) Aquatic risk assessment of herbicides in freshwater ecosystems of South Florida. Arch Environ Contam Toxicol 54: 571-583.

Seguin F, Leboulanger C, Rimet F, Druart JC, Bérard A (2001) Effects of atrazine and nicosulfuron on phytoplankton in systems of increasing complexity. Arch Environ Contam Toxicol 40: 198-208. 
Seguin F, Le Bihan F, Leboulanger C, Bérard A (2002) A risk assessment of pollution: induction of atrazine tolerance in phytoplankton communities in freshwater outdoor mesocosms, using chlorophyll fluorescence as an endpoint. Wat Res 36: 3227-3236.

Shaw M, Negri A, Fabricius K, Mueller JF (2009). Predicting water toxicity: Pairing passive sampling with bioassays on the Great Barrier Reef. Aquat Toxicol 95: 108-116.

Sinclair CJ, Boxall ABA (2003) Assessing the ecotoxicity of pesticide transformation products. Environ Sci Technol 37: 4617-4625.

Slijkerman DME, Moreira-Santos M, Robbert GJ, Ribeiro R, Soares AMVM, van Straalen NM (2005) Functional and structural impact of linuron on a freshwater community of primary producers: The use of immobilized algae. Environ Toxicol Chem 24: 2477-2485.

Solomon KR, Baker DB, Richards RP, Dixon KR, Klaine SJ, La Point TW, Kendall RJ, Weisskopf CP, Giddings JM, Giesy JP, Hall LW, Williams WM (1996) Ecological risk assessment of atrazine in North American surface waters. Environ Toxicol Chem 15: 3176.

Spawn RL, Hoagland KD, Siegfried BD (1997) Effects of alachlor on an algal community from a midwestern agricultural stream. Environ Toxicol Chem 16: 785-793.

Takahashi Y, Houjyo T, Kohjimoto T, Takagi Y, Mori K, Muraoka T, Annoh H, Ogiyama K, Funaki Y, Tanaka K, Wada Y, Fujita T (2007) Impact of pretilachlor herbicide and pyridaphenthion insecticide on aquatic organisms in model streams. Ecotoxicol Environ Safe 67: 227-239.

Tlili A, Dorigo U, Montuelle B, Margoum C, Carluer N, Gouy V, Bouchez A, Bérard A (2008) Responses of chronically contaminated biofilms to short pulses of diuron: An experimental study simulating flooding events in a small river. Aquat Toxicol 87: 252263.

Tlili A, Bérard A, Roulier JL, Volat B, Montuelle B (2010) $\mathrm{PO}_{4}{ }^{3-}$ dependence of the tolerance of autotrophic and heterotrophic biofilm communities to copper and diuron. Aquat Toxicol 98: 165-177.

Tlili A, Montuelle B (2011) Microbial Pollution-Induced Community Tolerance, in: AmiardTriquet C, Rainbow PS, Roméo M (Eds.) Tolerance to Environmental Contaminants. CRCpress. p. 85-108.

Tlili A, Montuelle B, Bérard A, Bouchez A (2011) Impact of chronic and acute pesticide exposures on periphyton communities. Sci Total Environ 409: 2102-2113 
Traunspurger W, Schäfer H, Remde A (1996) Comparative investigation on the effect of a herbicide on aquatic organisms in single species tests and aquatic microcosms. Chemosphere 33: 1129-1141.

Valiente Moro C, Crouzet O, Rasconi S, Thouvenot A, Coffe G, Batisson I, Bohatier J (2009) New design strategy for development of specific primer sets for PCR-based detection of Chlorophyceae and Bacillariophyceae in environmental samples. Appl Environ Microbiol 75: 5729-5733.

Van den Brink PJ, Van Donk E, Gylstra R, Crum SJH, Brock TCM (1995) Effect of chronic low concentrations of the pesticides chlorpyrifos and atrazine in indoor freshwater microcosms. Chemosphere 31: 3181-3200.

Van den Brink PJ, Hartgers EM, Fettweis U, Crum SJH, Van Donk E, Brock TCM (1997) Sensitivity of macrophyte-dominated freshwater microcosms to chronic levels of the herbicide linuron. Ecotox Environ Safe 38: 13-24.

Van den Brink PJ, Crum SJH, Gylstra R, Bransen F, Cuppen JGM, Brock TCM (2009) Effects of a herbicide-insecticide mixture in freshwater microcosms: Risk assessment and ecological effect chain. Environ Pollut 157: 237-249.

Van Geest GJ, Zwaardemaker NG, Van Wijngaarden RPA, Cuppen JGM (1999) Effects of a pulsed treatment with the herbicide afalon (active ingredient linuron) on macrophytedominated mesocosms. II. Structural responses. Environ Toxicol Chem 18: 2866-2874.

Van Wijngaarden RPA, Cuppen JGM, Arts GHP, Crum SJH, van den Hoorn MW, van den Brink PJ, Brock TCM (2004) Aquatic risk assessment of a realistic exposure to pesticides used in bulb crops: A microcosm study. Environ Toxicol Chem 23: 1479-1498.

Vera MS, Lagomarsino L, Sylvester M, Pérez GL, Rodríguez P, Mugni H, Sinistro R, Ferraro M, Bonetto C, Zagarese H, Pizarro H (2010) New evidences of Roundup®) (glyphosate formulation) impact on the periphyton community and the water quality of freshwater ecosystems. Ecotoxicology 19: 710-721.

Villeneuve A, Montuelle B, Bouchez A (2011) Effects of flow regime and pesticides on periphytic communities: evolution and role of biodiversity. Aquat Toxicol 102:123-133.

Waiser MJ, Robarts RD (1997) Impacts of a herbicide and fertilizers on the microbial community of a saline prairie lake. Can J Fish Aquat Sci 54: 320-329.

Wellmann P, Ratte HT, Heimbach F (1998) Primary and secondary effects of methabenzthiazuron on plankton communities in aquatic outdoor microcosms. Aquat Ecol 32: $125-134$. 
Wendt-Rasch L, Pirzadeh P, Woin P (2003) Effects of metsulfuron methyl and cypermethrin exposure on freshwater model ecosystems. Aquat Toxicol 63: 243-256.

Wendt-Rasch L, Van den Brink PJ, Crum SJH, Woin P (2004) The effects of a pesticide mixture on aquatic ecosystems differing in trophic status: responses of the macrophyte Myriophyllum spicatum and the periphytic algal community. Ecotox Environ Safe 57: 383-398.

Woudneh MB, Ou Z, Sekela M, Tuominen T, Gledhill M (2009) Pesticide multiresidues in waters of the lower Fraser valley, British Columbia, Canada. Part I. Surface water. J Environ Qual 38: 940-947. 


\section{Tables}

Table 1 Main characteristics of the herbicides cited in this review (source: Footprint Database; http://www.eu-footprint.org/)

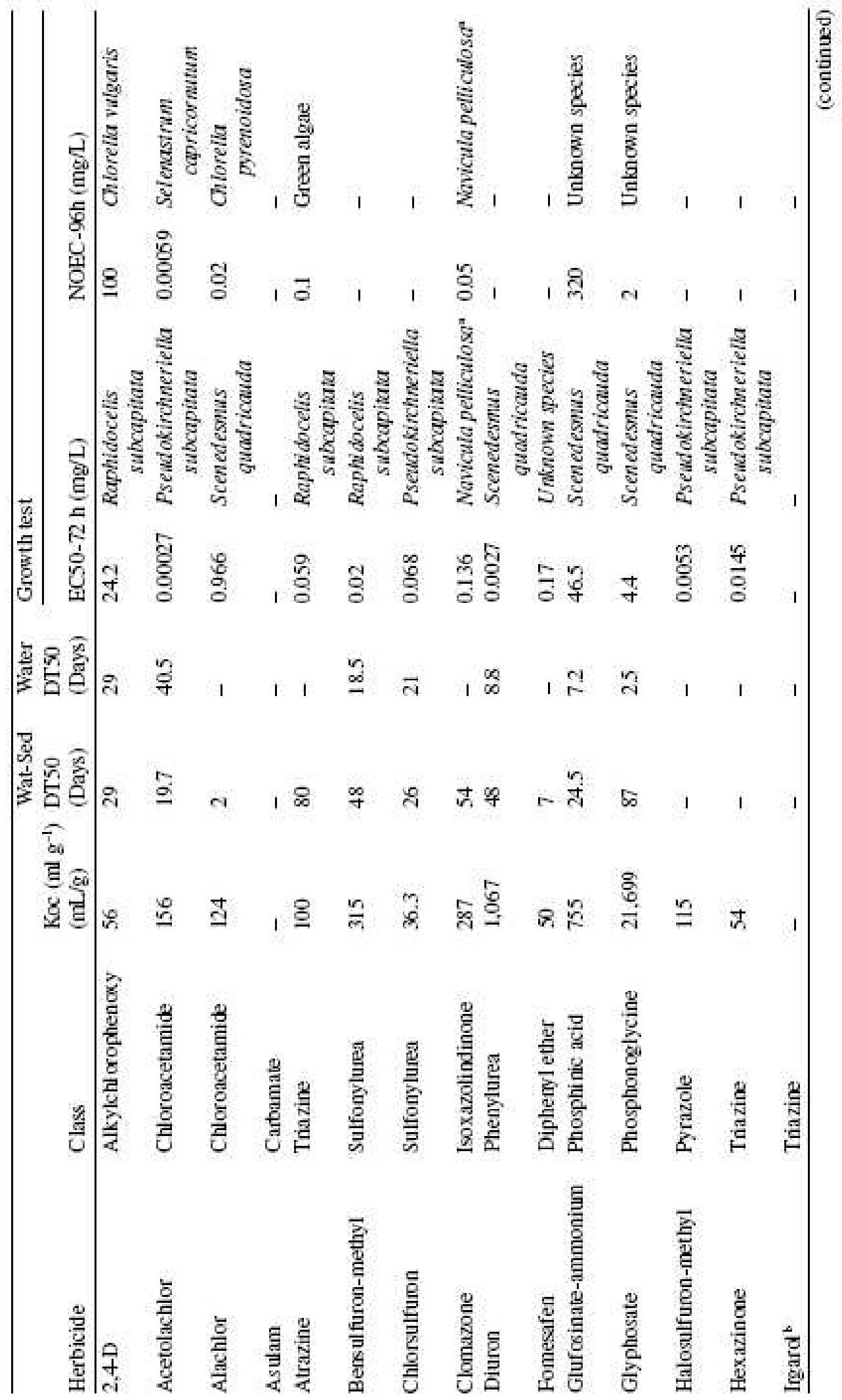


Table 1 (continuated)

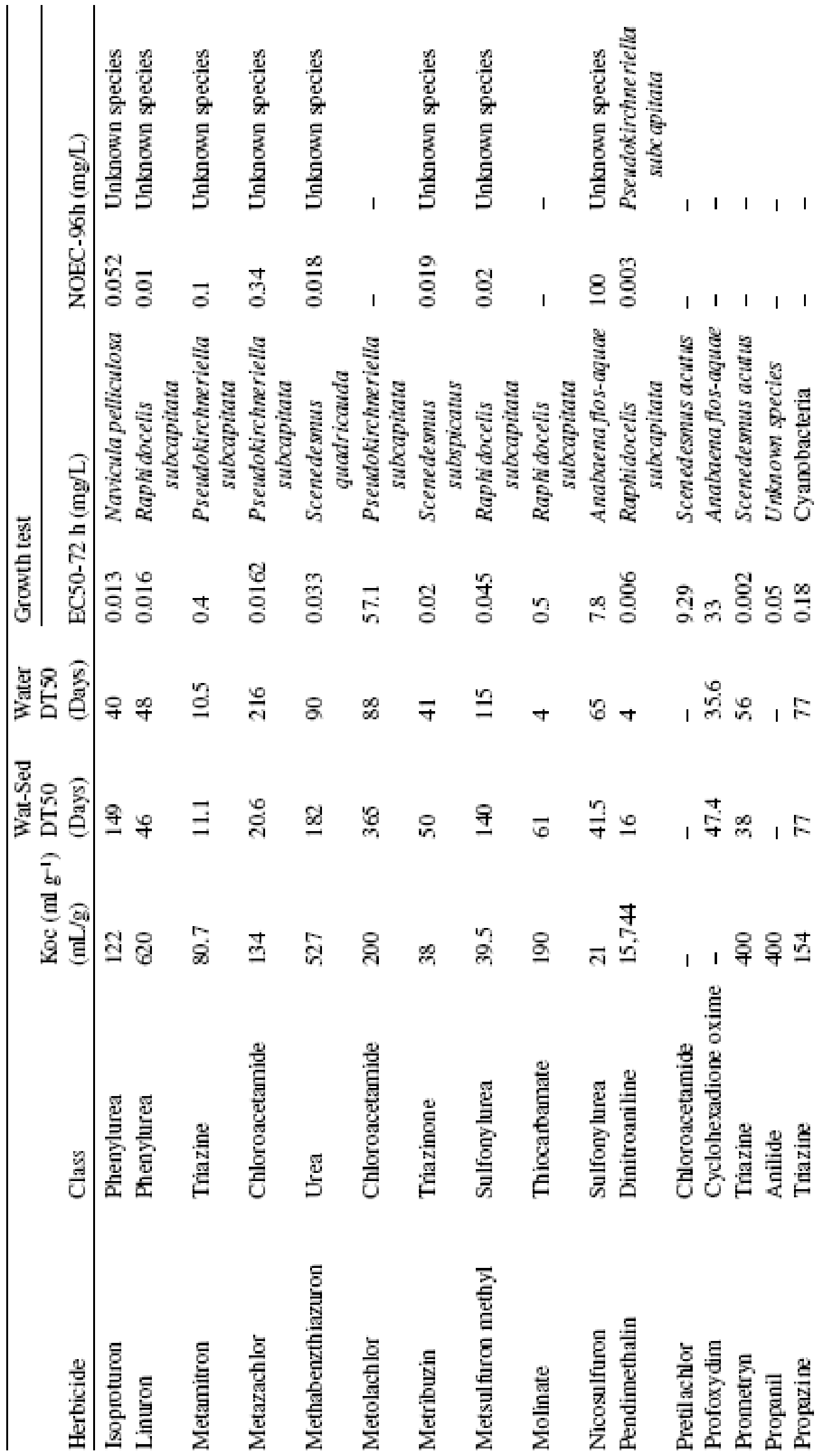


Table 1 (continuated)

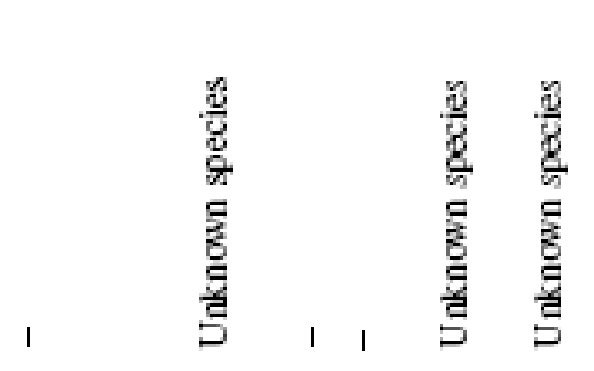

$$
\begin{aligned}
& 1 \text { 1 ๖ํ } 111 \text { हैं } \infty
\end{aligned}
$$

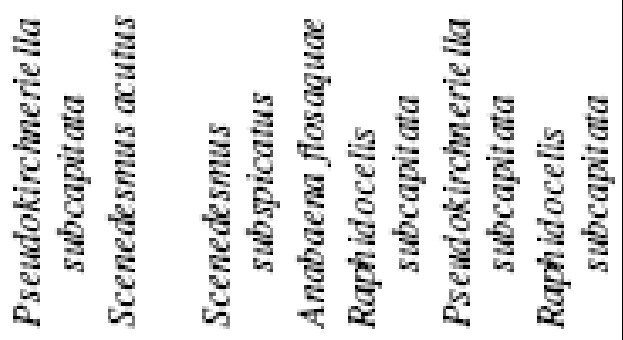

$$
\begin{aligned}
& \text { 잉 }
\end{aligned}
$$

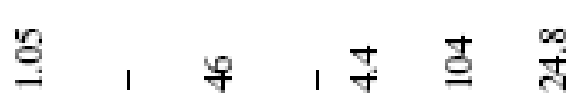

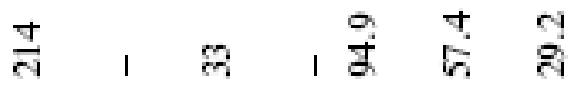

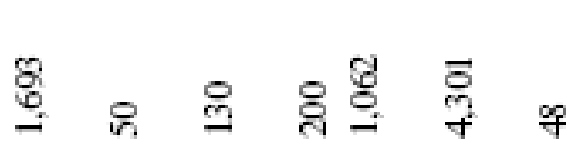

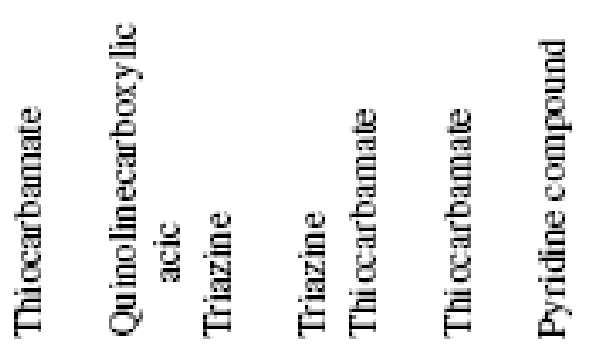


Table 2 Summary list of studies in which the effects of atrazine were assessed on phototrophic freshwater microbial communities in experimental systems

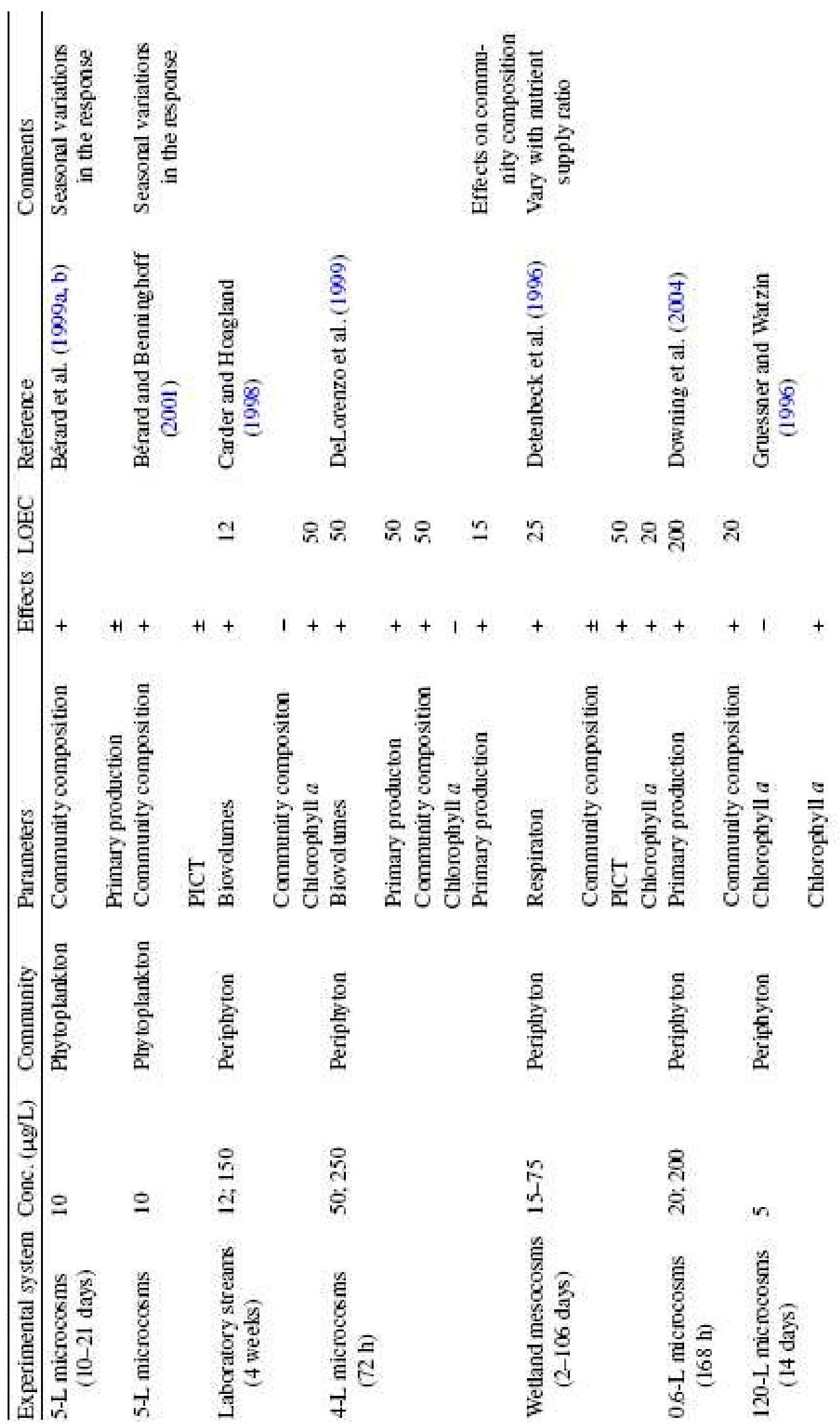


Table 2 (continuated)
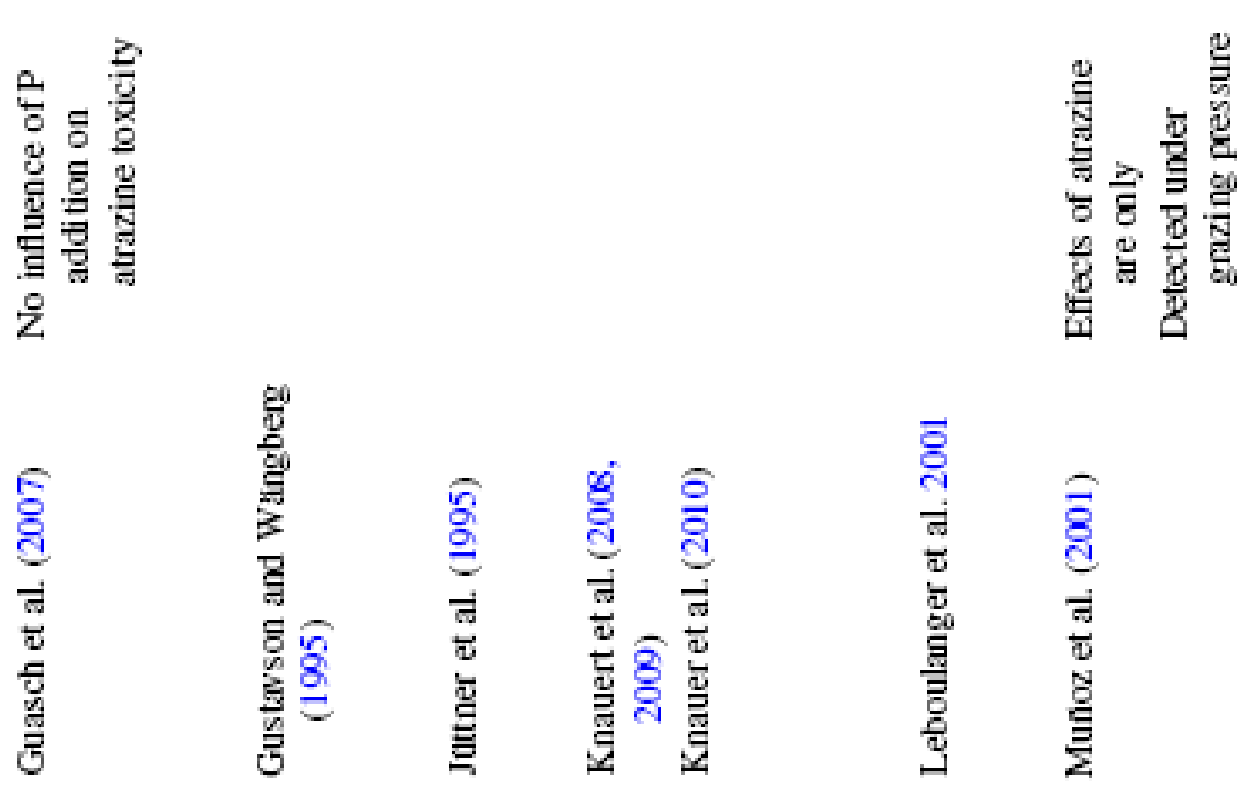

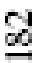
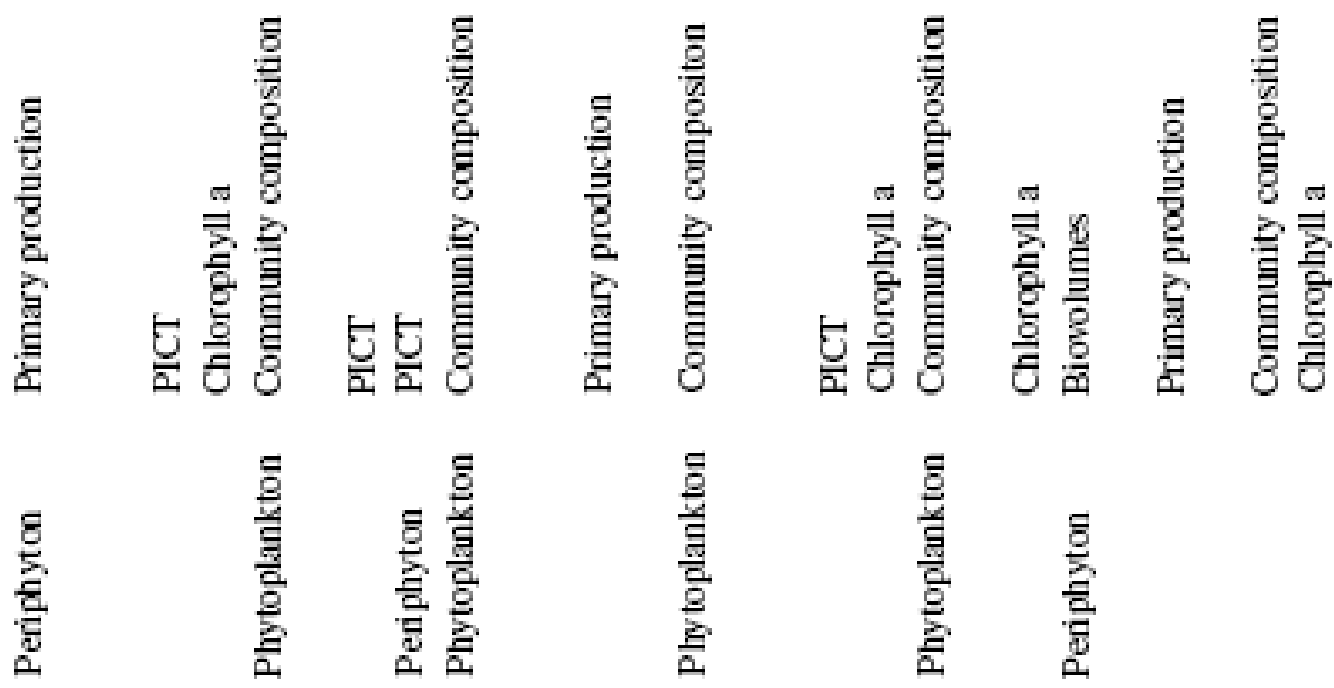

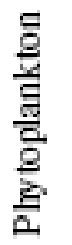

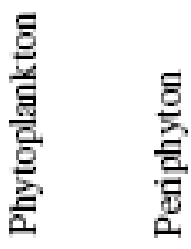

요

ิㅗ

$\frac{\infty}{n}$

R

\pm

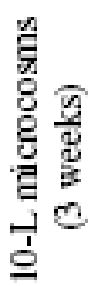

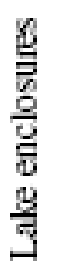
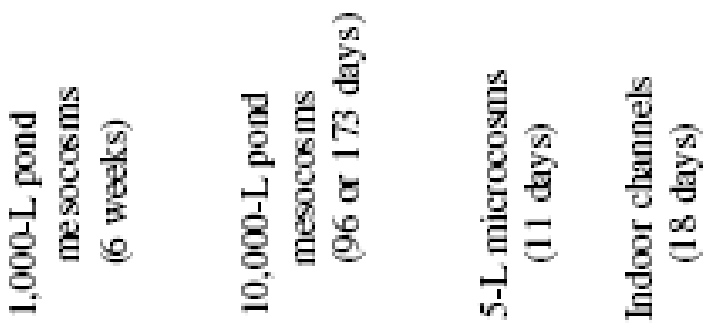
Table 2 (continuated)
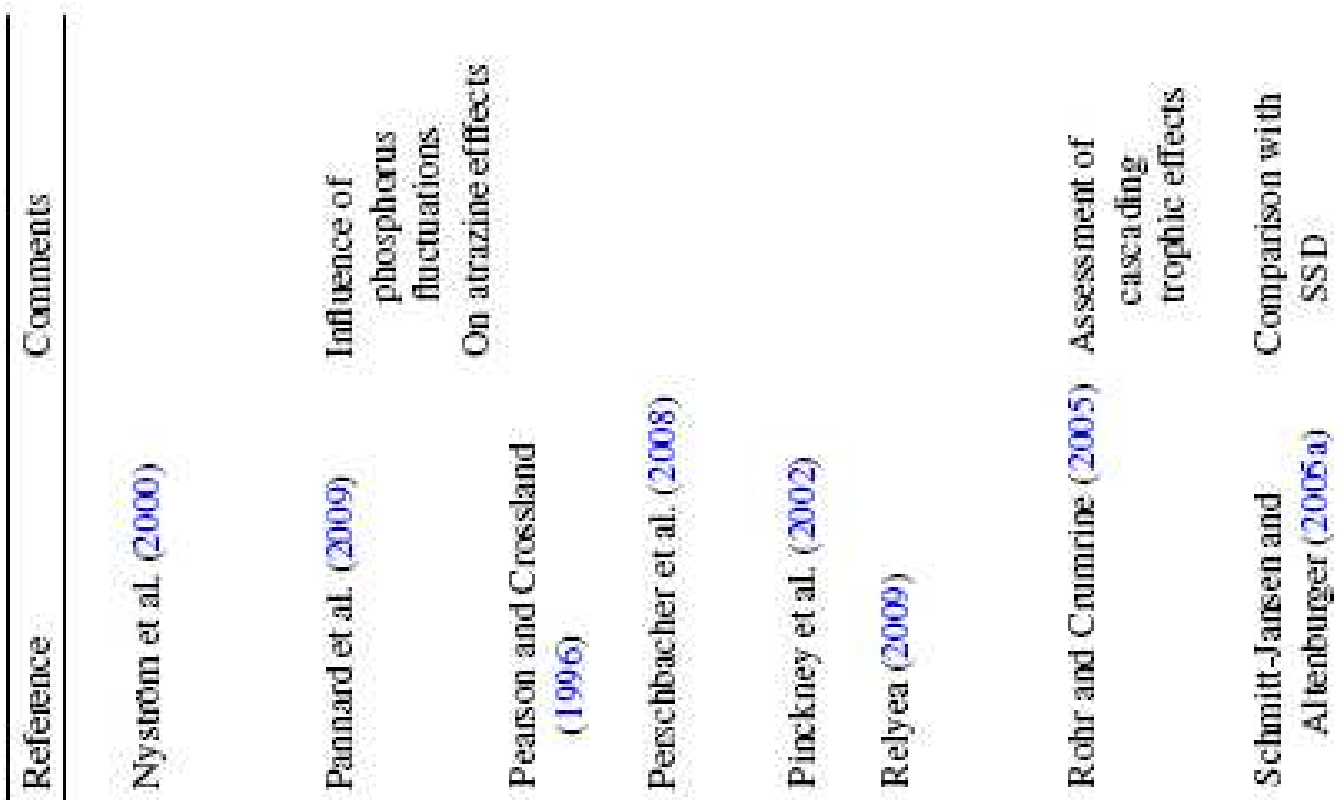

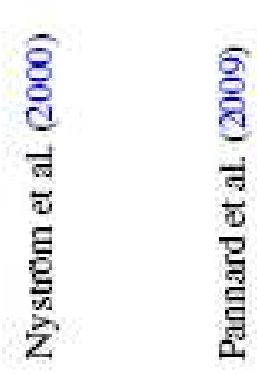

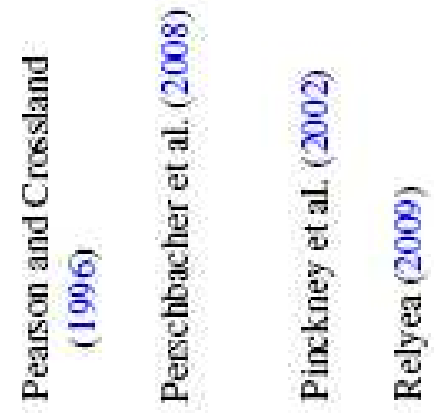

в 듸 $\overrightarrow{0}$ 을

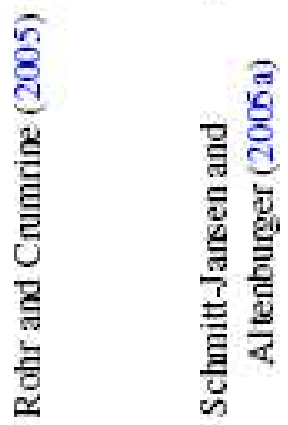

造

$+$

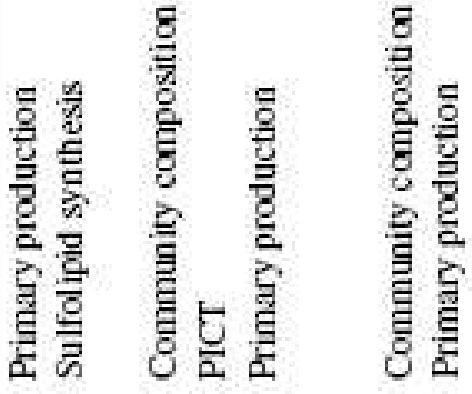

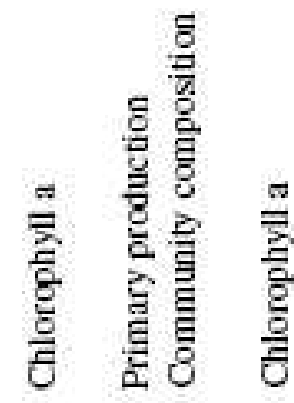

88 ำ

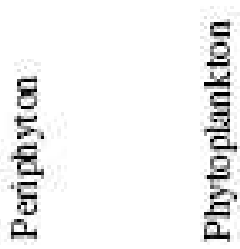

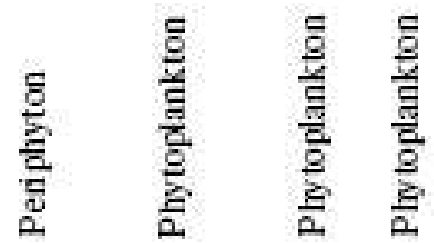

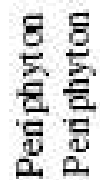

突

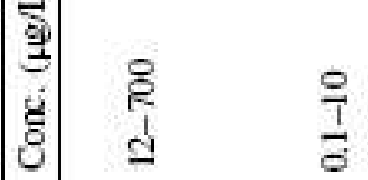

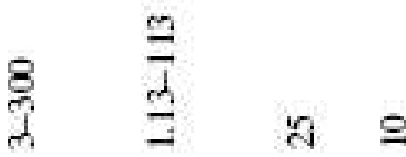

$2 \quad \begin{gathered}8 \\ 0\end{gathered}$
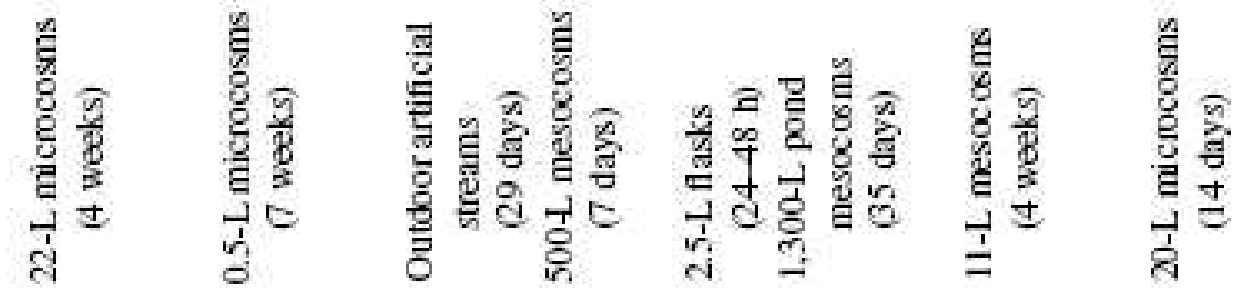
Table 2 (continuated)




Table 3 Summary list of studies in which the effects of diuron were assessed on phototrophic freshwater microbial communities in experimental systems

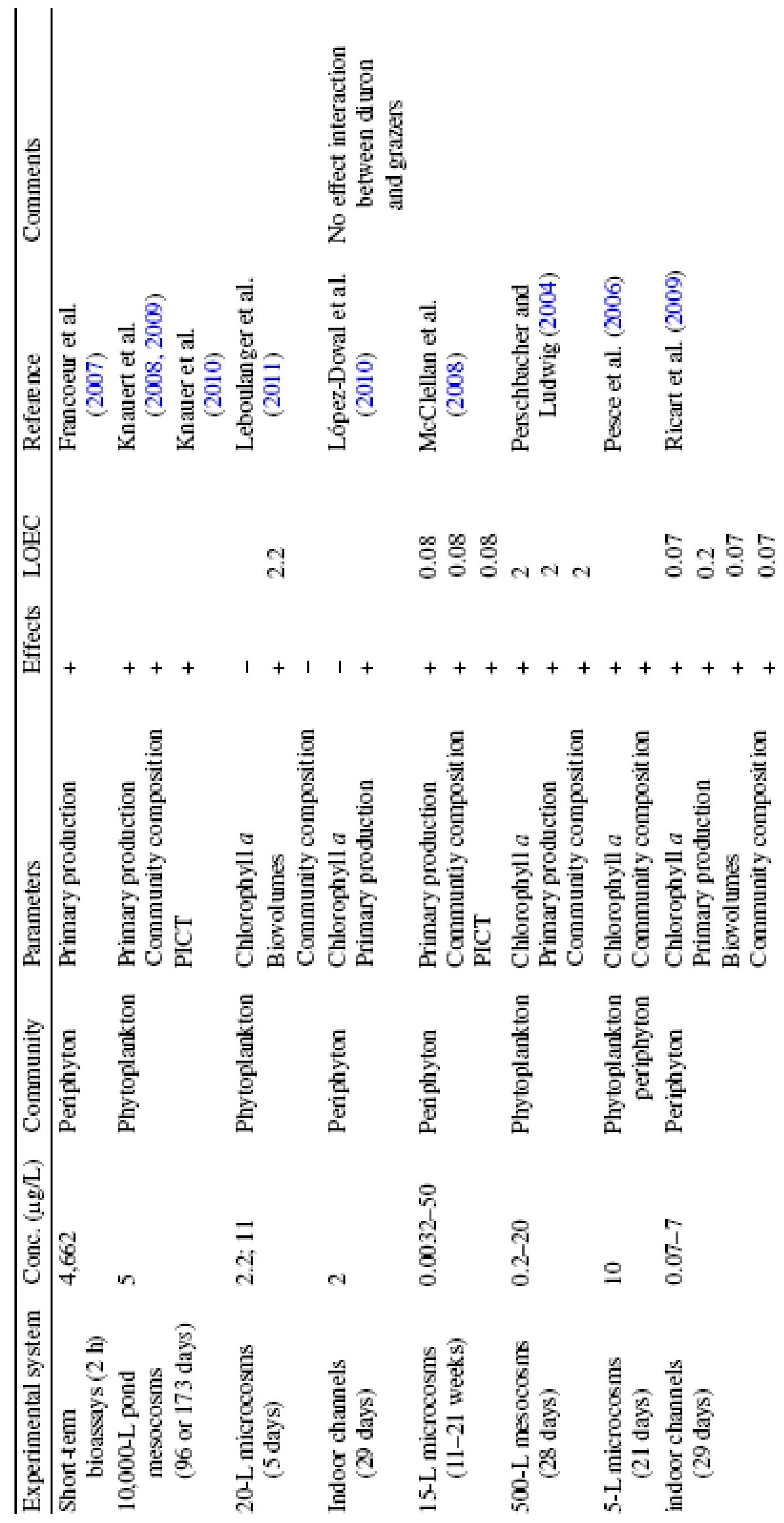


Table 3 (continuated)

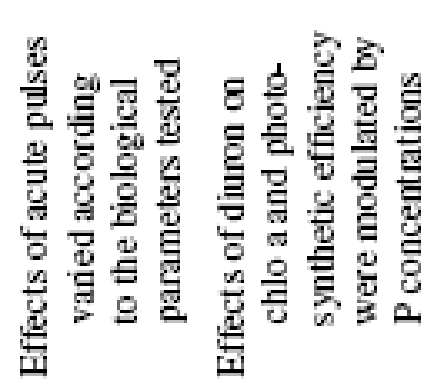

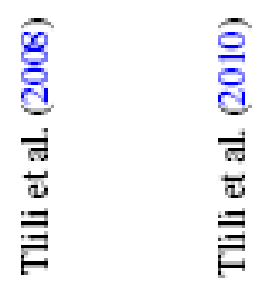

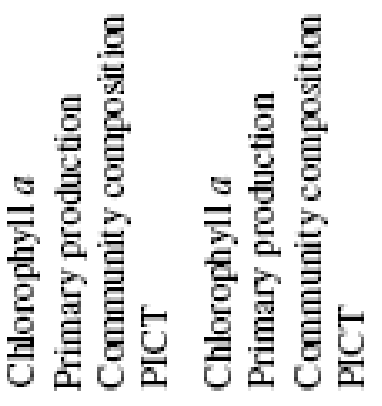

焉 递

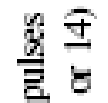

$\pm^{2}$

으

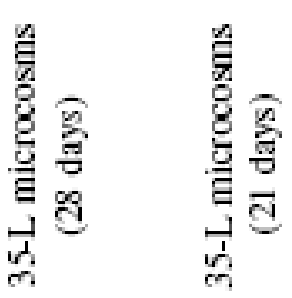

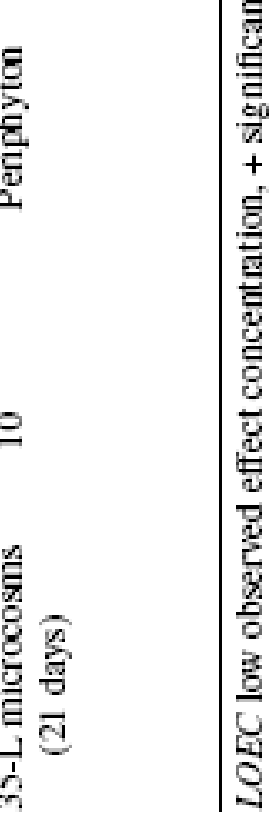

